\title{
One Thousand 1960 Books for the Lower-Division College Library
}

By ROBERT C. JONES

$\mathrm{T}$ His compilation of books published in 1960 is a continuation of similar lists for 1958 and 1959 of " 750 Desirable Books" compiled by Robert T. Jordan. ${ }^{1}$

There are many problems in assembling a list of books of a single year in time for it to be fully useful and many problems in selecting books desirable for the majority of the undergraduate libraries. Outstanding among these difficulties is the fact that about the only item these libraries have in common is dissimilarity. Undergraduate libraries (these include two-year institutions, the junior colleges, and the community colleges) are different not only from state to state, but also from community to community. This is as it should be. Each institution and each library must serve its own needs, based upon the character of its enrollment, its curriculum, and the specific needs of its students, faculty, and community. The undergraduate years are the formative years, and the library must provide in breadth what it does not necessarily need in depth; however, the advanced student cannot be handicapped by a lack of advanced material. Increasing numbers of two-year college students now transfer to four-year colleges and universities, and they are more than holding their own academically with the native students of the institution. An undergraduate library low on quality and quantity of books is rendering a great disservice to the student and the community.

This 1960 list was increased to a thousand titles to make the total of the 19581960 lists twenty-five hundred. It leaves

1 Robert T. Jordan, "Best Books for Lower-Division College Library," Library Journal, LXXXIII (1960), 2535-2538.
Dr. Jones is Director of Library Services, American River Junior College, Sacramento, Calif.

ample opportunity for individual libraries to build up special areas as required by the curriculum, but no list can substitute for effective librarian-faculty cooperation in book selection. Surely a minimum of twenty-five hundred acquisitions per year is necessary, and a total of twenty-five thousand volumes is probably minimal for an adequate library. Standard book selection aids have been used throughout the year to make these selections. Library of Congress card and classification numbers and prices for the titles are noted.

\section{GENERAL WORKS}

Berlo, David Kenneth. The process of communication. Holt. 006/60-7981/ $\$ 4.25$

Powell, Lawrence C. Books in my baggage; adventures in reading and collecting. World. 010/59-11538/ $\$ 4.50$

Fadiman, Clifton. The lifetime reading plan. World. 016.028/60-5810/\$3.75

Hoffman, Hester R. (ed.). The reader's adviser and bookman's manual. 9th ed. rev. and enl. Bowker. 016.028/57-13277 $\mathrm{rev} / \$ 15.00$

Weber, J. Sherwood (ed.). Good reading. Bowker. 016.028/33-10540/\$4.00

Poteat, Dorothy Mae. Basic materials for Florida Junior College Libraries; Magazines. Florida State Dept. of Education, 016.051/60-63525/\$1.00

Schab, William H. Monuments of book illustration, early printing, and manuscripts from the XVth to the XVIIth centuries. Schab. 016.09/60-1341/ $\$ 3.00$

Marshall, John D. (comp.). Of, by, and for 
librarians. Shoe String. 020.4/60-10701/ $\$ 7.00$

Bonn, George S. Training laymen in use of the library. 2 v. in 1. Graduate School of Library Service, Rutgers. 020.82/60-7280/ $\$ 5.00$

Ellsworth, Ralph E. Buildings. $3 \mathrm{v}$. in 1. Graduate School of Library Service, Rutgers. 022.082/60-7279/ $\$ 5.50$

California Univ. The climate of book selection. Univ. of Calif. 025.2106379467/59$12887 / \$ 2.50$

Tauber, Maurice F. Cataloging and classification. Graduate School of Library Service, Rutgers. 025.3/60-7278/ $\$ 8.00$

LydENBERG, HARRY M. The care and repair of books. 4th rev. ed. Bowker. 025.7/60$11980 / \$ 6.15$

Bryant, Eric T. Music Librarianship. Hafner. 026.78/60-403/ $\$ 6.50$

Larrick, Nancy. A teacher's guide to children's books. Merrill. 028.52/60-14777/ $\$ 4.95$

American Association of School LibrarIANs. Standards for school library programs. 028.82/60-7349/ $\$ 2.50$

Hohenberg, John. The professional journalist. Holt. 070.431/60-7795/ $\$ 5.50$

DAVENPORT, WALtER. Ladies, gentlemen and editors. Doubleday. 070.69/60-11379/ $\$ 4.95$

Kobre, Sidney. Modern American journalism. Florida State Univ. 071.3/60-62978/ $\$ 5.95$

Lindstrom, Carl E. The fading American newspaper. Doubleday. 071.3/60-13541/ $\$ 3.95$

Lord, Walter. The good years, from 1900 to the 1st World War. Harper. 073.91/59$10585 / \$ 4.95$

Bryson, Lyman L. (ed.). An outline of man's knowledge of the modern world. McGraw-Hill. 082/60-8273/\$7.50

\section{PHILOSOPHY \& PSYCHOLOGY}

Thalheimer, Ai.vin. Existential metaphysics. Philosophical Lib. 111.1/60-15963/\$7.50

Winn, RaLph B. A concise dictionary of existentialism. Philosophical Lib. 111.103/60$16177 / \$ 3.75$

Rader, Melvin M. (ed.). A modern book of esthetics. 3rd ed. Holt. 111.85/60-8597/ $\$ 6.75$

Read, Sir Herbert E. The forms of things unknown. Horizon. 111.85/60-14683/ $\$ 6.00$

Feifel, Herman (ed.). The meaning of death. McGraw-Hill. 128.5/59-15049/ $\$ 6.50$

Sandbeck, Hans C. Nature and destiny. N.Y., Humanities. 128.5/60-2533/ $\$ 6.00$

Hook, Sidney (ed.). Dimensions of mind. 3rd ed. Univ. Press. 130.1/60-9403/ $\$ 5.00$

Andreas, Burton G. Experimental psychology. Wiley. 131/60-11716/\$6.95

Deutsch, Jaroslav A. The structural basis of behavior. Univ. of Chicago. 131/60-12466/ $\$ 3.50$

International Conference. The student and mental health. World Federation for Mental Health Year. 131.3/59-16938/\$5.00

ThORPE, Louis P. The psychology of mental health. 2nd ed. Ronald. 131.3/60-6150/ $\$ 6.50$

Cottle, William C. Procedures and preparation for counseling. Prentice-Hall. 131. $322 / 60-9576 / \$ 8.00$

Jones, Richard M. An application of psychoanalysis to education. Charles Thomas. $131.34 / 59-14925 / \$ 5.50$

KretsChMER, ERnSt. Hysteria, reflex and instinct. Philosophical Lib. 132.15/60-13651/ $\$ 4.75$

Saul, Leon J., M.D. Emotional maturity. Lippincott. 132.15/59-15264/ $\$ 6.50$

James, William. William James on psychical research. Viking. 133.07/60-1 1807/ $\$ 6.00$

Sudre, Rene. Parapsychology. Citadel. 133. 07/60-13928/ $\$ 6.00$

WedEck, Harry. Treasury of witchcraft. Philosophical Lib. 133.4/60-15919/\$10.00

RFIK, THEODor. Sex in man and woman. Noonday. 136.11/60-15139/\$4.50

Fuller, John L. Behavior genetics. Wiley. 136.3/60-11722/\$8.95

Belo, JANE. Trance in Bali. Columbia Univ. $136.49923 / 60-6545 / \$ 7.50$

Breckenridge, Marian. Child development. 4 th ed. Saunders. $136.7 / 60-9822 / \$ 6.50$

Martin, William E. Child behavior and development. Harcourt. 136.7/59-7736/ $\$ 6.00$

Schneiders, Alexander A. Personality development and adjustment in adolescence. Bruce. 136.7354/60-14397/ $\$ 5.75$

Seidman, Jerome M. (ed.). The adolescent. Rev. ed. Holt. 136.7354/60-6634/\$6.50

Strang, Ruth M. Helping your gifted child. Dutton. $136.765 / 60-5974 / \$ 4.50$

Allport, Gordon W. Personality and social encounter. Beacon. 137/60-14675/\$7.50

WEINBERG, HaRrY L. Levels of knowing and existence; studies in general semantics. Harper. 149.94/59-12676/ $\$ 4.50$ 
Hall, Calvin S. Psychology. Univ. Center Station. $150 / 60-10141 / \$ 5.50$

Miller, George A. Plans and the structure of behavior. Holt. 150.18/60-7982/ $\$ 5.00$

Levits, Morton. Freud and Dewey on the nature of man. Philosophical Lib. 150.19/ $60-1539 / \$ 3.75$

Baker, Lawrence M. General experimental psychology. Oxford. 150.72/59-10967/\$6.00

McGuican, Frank J. Experimental psychology. Prentice-Hall. 150.72/60-14197/\$6.00

Viaud, Gaston. Intelligence, its evolution and forms. Harper. 151/60-7546/ $\$ 2.25$

Kenmare, Dallas. The nature of genius. Fla. Transatlantic Arts. 151.1/60-3853/ $\$ 5.25$

Cronbach, Lee J. Essentials of psychological testing. Harper. 151.2/59-13919/\$7.00

Waters, Rolland H., (ed.). Principles of comparative psychology. McGraw-Hill. 151. 3/59.11949/\$7.95

Freud, Sigmund. Jokes and their relation to the unconscious. Norton. 153.8/60-15727/ $\$ 4.50$

Russell, William. Brain, memory, learning. C.larendon Press. 154/A60-4417/ $\$ 4.50$

LAIRd, Donald A. Techniques for efficient remembering. McGraw-Hill. 154.1/60-8837/ $\$ 3.95$

Spence, Kenneth W. Behavior theory and learning. Prentice-Hall. 154.4/60-14658/ $\$ 9.00$

Summerfield, Jack D. (ed.). The creative mind and method. Univ. of Texas. 155.3/ $60-14308 / \$ 3.00$

Arnold, Magda B. Emotion and personality. 2 v. Columbia. 157.2/60-7481/ $\$ 7.50$

Rokeach, Milton. The open and closed mind. Basic Books. 157/60-5888/ $\$ 7.50$

Pavlov, Ivan P. Conditioned reflexes. Dover. $158.423 / 60-2546 / \$ 2.25$

McKinney, Fred. Psychology of personal adjustment. Wiley. 159/60-5602/\$6.50

Halberstadt, William H. An introduction to modern logic. Harper. 164/60-7009/ $\$ 5.00$

Maurois, André. The art of living. Harper. $170 / 59-65341 / \$ 3.50$

Adkins, Arthur W. H. Merit and responsibility. Oxford. 170.938/60-811/ $\$ 6.75$

Badarayana. The Brahma sutra, philosophy of spiritual life. Harper. 181.48/60-1206/ $\$ 10.00$

Plato. The myths of Plato. So. I1l. Univ. $184 / 60-9248 / \$ 12.50$
Bronowski, Jacoв. The Western intellectual tradition. Harper. 190/59-12671/ $\$ 7.50$

Urmson, J. O. (ed.). The concise encyclopedia of Western philosophy and philosophers. Hawthorn. 190.3/60-6258/\$12.95

Frankel, Gharles (ed.). The golden age of American philosophy. Braziller. 191.082/ $60-5612 / \$ 7.50$

Muelder, Walter G. (ed.). The development of American philosophy. 2nd ed. Houghton Mifflin. 191.0822/60-16272/\$7.00

Hegel, Grorg W. Encyclopedia of philosophy. Philosophical Lib. 193/59-65323/\$6.00

LeOnardo da Vinci. Philosophical diary. Philosophical Lib. 195/59-16511/ \$2.75

\section{RELIGION}

Glenn, Paul J. A tour of the Summa. Herder Book. 208.1/60-16942/\$5.00

Mathison, Richard R. Faiths, cults and sects of America: from atheism to Zen. BobbsMerrill. 209.73/60-13589/\$5.00

Olmstead, Clifton E. History of religion in the U. S. Prentice-Hall. 209.73/60-10355/ $\$ 10.00$

Spence, Hartzell. The story of America's religions. Holt. 209.73/60-12319/\$14.95

Shapley, Harlow (ed.). Science ponders religion. Appleton. 215/60-15840/ $\$ 5.00$

Neil, William (ed.). The Bible companion. McGraw-Hill. 220.02/59-12350/\$9.95

Neilson, Francis. From Ur to Nazareth. Robert Schalkenbach Foundation. 220.95/60$1483 / \$ 6.00$

ReIK, Theodor. The creation of woman. Braziller. 222.11/60-5613/\$3.75

TAYlor, Marvin J. (ed.). Religious education. Abingdon. 268.082/60-5477/\$6.50

Maus, Cynthia P. (comp.) The church and the fine arts. Harper. 270.082/60-7956/ $\$ 6.95$

Smith, Hilrif S. American Christianity. v. 1-1607-1820. Scribners. 277.3/60-8117/ $\$ 10.00$

James, Edwin O. The ancient Gods. Putnam. $290 / 60-8472 / \$ 7.50$

Paul Carus Memorial Symposium, Peru, 111. Modern trends in world religions. Open Court. 290.82/60-1277/ $\$ 3.50$

Swanson, Guy E. The birth of the gods. Univ, of Mich. 291.2/60-9974/\$4.95

Kerenyi, Karoly. The heroes of the Greeks. Grove. 292/60-8387/ $\$ 6.50$ 
Seltman, Charles T. The twelve Olympians. Crowell. 292.211/60-9164/ $\$ 4.50$

Hayakawa, Sessue K. Zen showed me the way. Bobl)s-Merrill. 294.329/60-13600/\$3.95

Watts, Alan W. This is it, and other essays on Zen and spiritual experience. Pantheon Books. 294.329/60-11758/\$3.50

Agus, Jacob B. The evolution of Jewish thought. Abelard-Schuman. 296/59-5612/ $\$ 7.50$

Clark, Robert T. R. Myth and symbol in ancient Egypt. Grove. 299.31/60-9260/ $\$ 5.00$

Kreler, Clyde E. Secrets of the Cuna earthmother. Exposition. 299.7/60-686/ $\$ 6.00$

La Barre, Weston. The peyote cult. Shoe String. 299.7/60-572/ $\$ 4.00$

\section{SOCIAL SCIENCES}

Gibson, Quentin B. The logic of social enquiry. Humanities. $300.18 / 60-2505 / \$ 6.00$

Durkheim, Emine. Montesquieu and Rousseau. Univ. of Mich. 301/60-5669/\$3.95

JoHNSON, HaRRY M. Sociology. Harcourt. $301 / 60-10390 / \$ 6.95$

Landis, Paul H. Social problems in nation and world. Lippincott. 301/59-8182/\$6.75

Mills, Charles W. (ed.). Images of man. Braziller. 301.082/60-8989/\$7.50

Martindale, Don A. The nature and types of sociological theory. Houghton. 301.09/ $60-50843 / \$ 6.50$

Cartwright, Dorwin (ed.). Group dynamics. 2nd. ed. Row, Peterson. 301.15/60-3229/ $\$ 7.25$

WARTERs, JANE. Group guidance, principles and practices. McGraw-Hill. 301.15/60. I $1966 / \$ 6.25$

Form, William H. Industry, labor and community. Harper. 301.153/60-7008/ $\$ 9.00$

Horton, Paul B. The sociology of social problems. 2nd ed. Appleton. 301.153/60$9625 / \$ 6.50$

Schettler, Clarence H. Public opinion in American society. Harper. 301.154/60. $7013 / \$ 7.00$

Houle, Cyril O. The effective board. Assoc. $301.1583 / 60-6560 / \$ 3.50$

KNight, Everitt W. The objective society. Braziller. 301.2/60-6988/\$3.75

Johnson, Leonard G. The social evolution of industrial society. Humanities. 301.243/ $59-49284 / \$ 5.50$
Mann, Floyd C. Automation and the worker. Rinehart. 301.243/60-7194/\$4.50

Ropke, Wilhelm. A humane economy. $\mathrm{H}$. Regnery. 301.243/60-9661/ $\$ 5.00$

Vogt, William. People: challenge to survival. Sloane. 301.32/60-13347/ $\$ 4.50$

Rogers, Everett M. Social change in rural society. Appleton. 301.35/60-7044/ $\$ 6.75$

Stein, Maurice R. The eclipse of community. Princeton Univ. 301.360973/60-5757/ $\$ 6.00$

Bloon, Robert O., JR. Husbands \& wives. Free Press. 301.42/59-6824/ $\$ 5.00$

Duvall, Evelyn R. Being married. Association Pr. 301.42/60-8522/ $\$ 4.95$

Kenkf.L, William $\mathrm{F}$. The family in perspective. Appleton. 301.42/60-5380/ $\$ 6.00$

Peterson. James A. Toward a successful marriage. Scribners. 301.42/60-6333/ $\$ 3.95$

Bell, Norman W. (ed.). A modern introduction to the family. Free Press. 301.42082/ 59-6823/\$7.56

Mace, David R. Marriage: East and West. Garden City, Doubleday. 301.42095/60$5944 / \$ 4.50$

Bowman, Henry A. Marriage for moderns. 4th ed. McGraw-Hill. 301.426/59-15455/ $\$ 9.50$

Elluis, Alber't. The art and science of love. Lyle Stuart. 301.426/60-6349/ $\$ 7.95$

Landis, Paul H. Making the most of marriage. 2nd ed. Appleton. 301.426/60-7024/ $\$ 6.75$

Landis, Judson T. Personal adjustment, marriage and family living. Prentice-Hall. 301. 426/60-7657/\$4.16

Popenoe, Paul. Can this marriage be saved. Macmillan. 301.426/60-8124/\$4.95

Rainwater, LeE. And the poor get children. Quadrangle Books. 301.426/60-10881/\$3.95

Bossard, James H. S. The sociology of child development. 3rd ed. Harper. 301.431/60$7016 / \$ 8.50$

Ginzberg, Eli (ed.). The nation's children. 3 v. Columbia Univ. 301.431973/60-8098/ $\$ 13.50$

Tibbitts, Clark (ed.). Aging in today's society. Prentice-Hall. 301.435/60-8763/\$6.00

Tibbitts, Clark (ed.). Handbook of social gerontology. Univ. of Chicago. 301.435/ $60-5469 / \$ 10.00$

Reissman, Leonard. Class in American society. Free Press. 301.440973/59-6825/ $\$ 6.75$

Huszar, George B. de (ed.). The intellectuals. Free Press. $301.445 / 60-8590 / \$ 7.50$ 
Ashmore, Harry S. The other side of Jordan. Norton. 301.451/60-12025/ $\$ 3.50$

Hand, Learned. The spirit of liberty. Knopf. $304 / 60-10956 / \$ 4.00$

Bonner, Thomas N. The contemporary world. Prentice-Hall. 309/60-8504/\$7.95

Blalock, Hubert M. JR. Social statistics. McGraw-Hill. 311.2/60-8825/\$7.95

Smith, C. Frank. Basic statistics for business economics. Irwin. 311.2/60-12923/ $\$ 8.00$

Cox, Peter R. Demography. Cambridge Univ. 312/60-16028/ $\$ 5.00$

Van Dyke, Vernon. Political science. Stanford Univ. 320.018/60-11836/\$5.00

Burns, Edward M. Ideas in conflict. Norton. 320.1/60-7571/ $\$ 9.25$

Verney, Douglas V. The analysis of political systems. Free Press. 320.1/60-1128/ $\$ 6.75$

Ebenstein, William. Modern political thought. 2nd ed. Holt. 320.4/60-15510/ $\$ 8.00$

Schmandt, Henry J. A history of political philosophy. Bruce. 320.9/60-10556/ $\$ 5.50$

Ehrenberg, Victor. The Greek State. Barnes \& Noble. 320.938/60-50246/\$7.00

Kornhauser, William. The politics of mass society. Free Press. 321.64/59-6820/\$5.00

Mayo, Henry B. An introduction to democratic theory. Oxford Univ. 321.8/60-7063/ $\$ 6.50$

Phillips, Norman C. The tragedy of apartheid. McKay. 323.168/60-15547/ $\$ 4.00$

Gellhorn, Walter. American rights. Macmillan. 323.40973/60-5408/\$4.50

Hayek, Friedrich A. The constitution of liberty. Univ. of Chicago. 323.44/59-11618/ $\$ 7.50$

Meiklejohn, Alexander. Political freedom. Harper. 323.443/60-5703/ $\$ 3.50$

Rogge, OetJe J. The first and the fifth. T. Nelson. 323.443/60-7292/ $\$ 8.50$

Downs, Robert B. (ed.). The first freedom. ALA. 323.445/59-13653/ $\$ 8.50$

Bozeman, AdDa B. Politics and culture in international history. Princeton Univ. 327. $09 / 60-5743 / \$ 10.00$

Barghoorn, Frederick C. The Soviet cultural offensive. Princeton Univ. 327.47/60$12227 / \$ 7.50$

Dallin, Alexander, comp. Soviet conduct in world affairs. Columbia Univ. 327.47/59$15509 / \$ 4.50$

Kulski, Wladyslaw W. Peaceful co-existence: an analysis of Soviet foreign policy. Regnery. 327.47085/59-13052/\$12.50
Saletore, Bhasker A. India's diplomatic relations with the West. W. S. Heinman. 327.54/58-11844/\$7.50

Davids, Jules. America and the world of our time. Random House. 327.73/60-5563/ $\$ 7.50$

Heilbroner, Robert L. The future as history. Harper. 327.73/60-7527/ $\$ 4.00$

Holt, Robert T. Strategic psychological operations and American foreign policy. Univ. of Chicago. 327.73/60-14238/\$5.00

Jacobson, Harold K. (ed.). America's foreign policy. Random House. 327.73/60$6196 / \$ 6.50$

KenNedy, JoHn F. The strategy of peace. Harper. 327.73/60-7530/\$3.50

Rostow, WALt W. The United States in the world arena. Harper. 327.73/60-7568/\$8.75

Stevenson, Adlai E. Putting first things first. Random House. 327.73/60-1097/ $\$ 3.00$

Thompson, Kenneth W. Political realism and the crisis of world politics. Princeton Univ. 327.73/60-5758/ $\$ 5.00$

Allen, Harry C. Conflict and concord. St. Martins. 327.73042/59-15565/\$3.75

Battistini, Lawrence $H$. The rise of American influence in Asia and the Pacific. Mich. State Univ. 327.7305/59-15833/ $\$ 5.00$

Campbell, John C. Defense of the Middle East (2d ed.). Harper. 327.73056/60-9110/ $\$ 5.00$

Haynes, George H. The Senate of the U. S. Russell \& Russell. 328.73/60-5280/\$15.00

VAN Riper, Paul P. Handbook of practical politics. 2d ed. Row, Peterson. 329/60$2401 / \$ 4.00$

Schapiro, Leonard B. The Communist Party of the Soviet Union. Random House. 329. 947/59-12309/ $\$ 7.50$

Peach, William N. Principles of economics. Rev. ed. R. D. Irwin. 330/60-14050/ $\$ 9.35$

DE Garmo, Earnest P. Engineering economy. Macmillan. 330.1/60-5033/\$8.75

Lauterbach, Albert T. Man, motives, and money. Cornell Univ. 330.1/60-192/\$5.00

TAYlOR, Overton H. A history of economic thought. McGraw-Hill. 330.109/60-8042/ $\$ 7.75$

Kish, George. Economic atlas of the Soviet Union. Univ. of Mich. 330.947/60-7/ $\$ 10.00$

United Nations. Economic survey of Africa since 1950. Columbia Univ. 330.96/60$1948 / \$ 3.00$

Cavis, Richard E. The Canadian economy. 
Harvard Univ. 330.971/59-14734/\$10.00

Hancogk, Ralph L. Puerto Rico. Van Nostrand. 330.97295/60-11064/\$4.75

Faulkner, Harold U. American economic history. 8th ed. Harper. 330.973/59-1391/ $\$ 7.00$

Resources for the Future. Regions, resources, and economic growth. Johns Hopkins. $330.973 / 60-12311 / \$ 12.00$

Pelling, Henry. American labor. Univ. of Chicago. 331.0973/60-7247 $/ \$ 5.00$

Magoun, F. Alexander. Cooperation and conflict in industry. Harper. 331.1/60 $5702 / \$ 4.50$

Young, Dallas M. Understanding labor problems. McGraw-Hill. 331.10973/59$11951 / \$ 7.95$

ALy, Bower (ed.). Labor and management. Noble \& Noble. 331.15082/59-4590/\$4.50

KenNedy, Robert $F$. The enemy within. Harper. 331.8808/60-6206/ $\$ 3.95$

Galenson, Walter (ed.). Labor and trade unionism. Wiley. 331.88082/60-10314/\$6.50

Dulles, Foster R. Labor in America. 2d rev. ed. Crowell. 331.880973/60-14543/\$5.50

Ross, Arthur M. Changing patterns of industrial conflict. Wiley. 331.892/60-10323/ $\$ 6.50$

Prochnow, Herbert V. The Federal Reserve System. Harper. 332.110973/60-6767/ $\$ 6.50$

Day, Alan C. Money and income. Oxford Univ. 332.4/59-7508/ $\$ 7.50$

Mayer, Martin. Wall Street. Harper. 332. $61097471 / 60-6041 / \$ 4.50$

JoRdan, David F. Investments. Prentice-Hall. $332.67 / 60-10550 / \$ 10.60$

Islam, Nurul. Foreign capital and economic development: Japan, India, and Canada. C. E. Tuttle. 332.763/60-5363/ $\$ 5.00$

Conrad, Joseph W. An introduction to the theory of interest. Univ. of Calif. 332.82/ $59-10463 / \$ 7.50$

North, Nelson L. Real estate. 5th ed. Prentice-Hall. 333.33/60-6301/ $\$ 9.25$

Rogers, George W. Alaska in transition. Johns Hopkins. 333.709798/59-14895/\$7.00

Draper, Theodore. American communism and Soviet Russia. Viking. 335.430954/60$7672 / \$ 8.50$

Prest, Alan R. Public finance in theory and practice. Quadrangle Books. 336/59-15517/ $\$ 7.50$

Holzman, Robert S. Federal income taxation. Ronald. 336.2402673/60-6155/\$8.00
Wilciox, Walter W. Economics of American agriculture. Prentice-Hall. 338.10973/60$10780 / \$ 8.75$

Stanford Research Inst. Small industry development organizations. Free Press. 338.7/ $59-65424 / \$ 10.00$

Eells, Richard S. The meaning of modern business. Columbia Univ. 338.74/60-8393/ $\$ 7.50$

Mason, Edward S. (ed.). The corporation in modern society. Harvard Univ. 338.740973/ 60-5392/\$6.75

Schlesinger, James R. The political economy of national security. Praeger. 338.9/ $60-7984 / \$ 5.00$

Watson, Donald S. Economic policy. Houghton Mifflin. 338.9/60-1608/\$7.50

Killough, Hugh B. International economics. Van Nostrand. 338.91/60-12865/\$6.50

Myrdal, Gunnar. Beyond the welfare state. Yale Univ. 338.91/60-7828/\$4.50

Chacko, George K. India. Bookman Associates. 338.954/59-14627/ $\$ 4.50$

Anderson, Ronald A. Government and business. 2d ed. Southwestern. 338.973/60-5826/ $\$ 7.00$

Rostow, Eugene V. Planning for freedom. Yale Univ. 338.973/59-12701 $/ \$ 6.00$

Theobald, Robirt. The rich and the poor. Clarkson N. Potter. 339/60-14427/ $\$ 4.50$

Packard, Vance $O$. The waste makers. D. McKay. 339.4/60-I 3330/\$4.50

McClure, Wallace. World legal order. Univ. of North Carolina. 341/60-25/\$7.50

Schwarzenberger, Georg. A manual of international law. Praeger, 341/60-11277/ $\$ 15.00$

Eichelberger, Clark M. UN: the first fifteen years. Harper. 341.13/60-10403/ $\$ 2.75$

Munro, Sir Leslie. United Nations; hope for a divided world. Holt. 341.13/60-5819/ $\$ 4.00$

Finfr, Herman. The major governments of modern Europe. Row, Peterson. 342.4/60$14418 / \$ 8.50$

Hazard, John N. The Soviet system of government. 2d ed. Univ. of Chicago. 342.47/ $60-14239 / \$ 4.00$

ScotT, Robert E. Mexican government in transition. Univ. of 111. 342.7203/59-10558/ $\$ 5.75$

Burns, James M. Government by the people. 4th ed. Prentice-Hall. 342.73/60-8502/\$7.95

Truman, Harry S. Truman speaks. Columbia Univ. 342.734/60-8389/ $\$ 3.00$ 
Pritchard, John L. A history of capital punishment. Citadel. 343.23/60-13927/\$5.00

Shepherd, Harold (ed.). Law in society. Foundation. 347.40973/60-2722/ $\$ 8.50$

Black, Charles L. The people and the court. Macmillan. 347.9973/60-5483/\$5.00

Schubert, Glendon A. Constitutional politics. Holt. 347.9973/60-11754/\$8.50

Gellhorn, Walter (ed.). Administrative law. 4th ed. Foundation. 351.950973/60-50352/ $\$ 12.50$

Brunton, Robert L. Management practices for smaller cities. Int'l. City Managers Assn. $352 / 59-8486 / \$ 7.50$

Connery, Robert H. The Federal Government and Metropolitan areas. Harvard Univ. 352.073/60-7990/\$4.75

Phillips, Jewell C. Municipal government and administration in America. Macmillan. $352.073 / 60-5247 / \$ 6.95$

Pfiffner, John M. Public administration. 4th ed. Ronald. 353/60-7771/\$7.00

Tugwell, Rexford G. The enlargement of the Presidency. Doubleday. 353.03/60 $113919 / \$ 6.95$

Neustadt, Richard E. Presidential power. Wiley. 353.032/60-9620/\$5.95

Anderson, William. Government in the fifty states. Holt. 353.9/60-9131/ $\$ 6.50$

MacDonald, Austin F. American state government and administration. 6th ed. Crowell. 353.9/60-6063/ $\$ 7.00$

Harvey, James, pseud. The British state. International Publications Service. 354.52/ $59.440 / \$ 4.50$

Buchan, Alastair. NATO in the 1960's. Praeger. 355/60-10484 $\$ 3.00$

Gaulle, Charles de. The edge of the sword. Criterion Books. 355/59-12197/ $\$ 3.50$

Hitch, Charles J. The economics of defense in the nuclear age. Harvard Univ. 355/60$10042 / \$ 9.50$

Liddell Hart, Basíl $H$. Deterrent or defense. Praeger. 355/60-12092/ $\$ 4.95$

Richardson, Lewis F. Arms and insecurity. Quadrangle Books. 355.01/59-9539/\$10.00

Kingston-McGloughry, Edgar James. Defense: policy and strategy. Praeger. 355. 0942/60-7662/\$6.00

TAYlor, Maxinell D. The uncertain trumpet. Harper. 355.0973/59-13290/\$4.00

Hunter, Mel. The missilemen. Garden City. Doubleday. 358.4174/60-5488/\$4.95

Pottrer, Elmer B. (ed.). Sea power; a naval history. Prentice-Hall. 359.09/60-15619/ $\$ 14.65$

Pierce, Philip N. The compact history of the United States Marine Corps. Hawthorn Books. 359.960973/60-5901/ $\$ 4.95$

Tappan, Paul W. Crime, justice and correction. McGraw-Hill. 364/59-15066/\$10.95

Abrahamsen, David. The psychology of crime. Columbia Univ. 364.34/59-13606/ $\$ 6.00$

Guttmacher, Manfred S. The mind of the murderer. Farrar Straus \& Cudahy. 364.34/ 60-7696/\$4.50

Robison, Sophia (Moses). Juvenile delinquency, its nature and control. Holt. 364. $36 / 60-7980 / \$ 6.75$

Richardson, John H. Economic and financial aspects of social security. Univ. of Toronto. 368.4/60-4332/\$4.50

Haber, William. Social security. Irwin. 368. $40973 / 60-15870 / \$ 8.75$

Bayles, Ernest E. Democratic educational theory. Harper. 370.1/60-5727/\$4.75

Glass, Hiram B. Science and liberal education. La. State Univ. 370.1/60-8285 $\$ \$ 3.00$

Hansen, Kenneth H. Philosophy for American education. Prentice-Hall. 370.1/60$11590 / \$ 5.50$

MAYer, Frederick. The goals of education. Public Affairs. 370.1/59-13658/ $\$ 3.25$

Mason, Robert E. Educational ideals in American society. Allyn \& Bacon. 370. 10973/60-7182/\$5.50

Burton, William H. Education for effective thinking. Appleton. 370.15/60-9925 $\$$ \$6.00

Cook, Lloyd A. A sociological approach to education. 3d ed. McGraw-Hill. 370.193/ $60-6964 / \$ 6.75$

Gruber, Frederick C. (ed.). Education and the state. Univ. of Pennsylvania. 370.193/ $60-8664 / \$ 2.75$

Stiles, Lindley J. Teacher education in the United States. Ronald. 370.7/60-7766/ $\$ 6.75$

Good, Harry G. A history of western education. 2d ed. Macmillan. 370.9/60-5063/ $\$ 6.50$

Mayer, Frederick. A history of educational thought. C. E. Merrill Books. 370.9/60$7692 / \$ 6.95$

Myers, Edward D. Education in the perspective of history. Harper. $370.9 / 60-7565 / \$ 6.00$

Bereday, George Z. F. (ed.). The changing Soviet school. Houghton Mifflin 370.947/ $60-16213 / \$ 6.50$

Berfday, Grorge Z. F. (ed.). The politics of 
Soviet education. Praeger. 370.947/60$6993 / \$ 6.00$

De Young, Chris A. American education. 4th ed. McGraw-Hill. 370.973/59-13199/ $\$ 6.50$

Peet, Harriet E. The creative individual. Ronald. 370.973/60-15022/ $\$ 4.50$

Wynne, John Peter (ed.). Qualities of experience and educational philosophy. Bookman Associate. 371.1/60-11330/\$3.50

Culbertson, Jack A. Administrative relationships. Prentice-Hall. 371.2/60-8214/ $\$ 6.75$

Remmers, Hermann H. A practical introduction to measurement and evaluation. Harper. 371.26/60-7012/\$4.75

BARNES, JoHN B. Educational research for classroom teachers. Putnam. 371.3072/60$13960 / \$ 4.00$

KLOPF, GoRdON J. College student government. Harper. 371.59/60-5701/\$3.50

Obersteuffer, Delbert. School health education. 3d. ed. Harper. 371.70/60-11612/ $\$ 6.00$

Bucher, Charles A. Foundations of physical education. 3d ed. Mosby. 371.73/60-8949/ $\$ 6.00$

Goldsen, Rose K. What college students think. Van Nostrand. 371.81/60-10288/ $\$ 5.95$

IngRam, Christine P. Education of the slowlearning child. $3 \mathrm{~d}$ ed. Ronald. 371.92/60$13149 / \$ 5.50$

Sumption, Merle R. Education of the gifted. Ronald. 371.95/60-7767/ $\$ 6.50$

KNAPP, ROBERT B. Social integration in urban communities. Teachers College, Columbia Univ. 371.97/60-13467/ $\$ 5.75$

Brickman, William W. (ed.). The countdown on segregated education. Society for the Advancement of Educ. 371.974/60$13498 / \$ 3.50$

LeE Johnathan. The child and his curriculum. 3d ed. Appleton. 372/60-8879/\$6.50

Jones, Arghie N. (ed.) Music and education in action. Allyn \& Bacon. 372.878/60-9622/ $\$ 7.25$

Patterson, Franklin K. The adolescent citizen. Free Press. 373/60-14403/ $\$ 6.00$

Gwynn, John M. Curriculum principles and social trends. 3d ed. Macmillan. 375/60$5020 / \$ 7.50$

MayHew, Lewis B. (ed.). General education. Harper. 378.01/60-7564/\$4.00

Shustr.r, George N. Education and moral wisdom. Harper. 378.081/60-5710/\$3.50

American Assembly. The Federal government and higher education. American Assembly, Columbia Univ. 378.1/60-13146/ $\$ 3.50$

Corson, JoHn J. Governance of colleges and universities. McGraw-Hill. 378.1/60-12765/ $\$ 5.50$

KeEzer, Dexter M. (ed.). Financing higher education, 1960-70. McGraw-Hill. 378.1/59$15194 / \$ 2.00$

McMahon, Ernest Edward. The emerging evening college. Teachers College, Columbia Univ. 378.15/60-12096/ $\$ 4.50$

Medsker, Leland L. The junior college: progress and prospect. McGraw-Hill. 378.$154 / 59-14459 / \$ 6.50$

Thornton, James W. The community junior college. Wiley. 378.154/60-11737/\$5.95

Hill, Alfred T. The small college meets the challenge. McGraw-Hill. 378.73/59-11933/ $\$ 4.95$

Seldon, William K. Accreditation; a struggle over standards in higher education. Harper. 378.73/60-5708/ $\$ 2.50$

Clark, Burton R. The open door college. McGraw-Hill. 378.79474/59-14440/\$5.00

Wash. State Univ. Man and learning in modern society. Univ. Wash. $378.79777 / 59$ $15076 / \$ 5.00$

Herndon, Booton. Young men can change the world. McGraw-Hill. 382.0621/60-697I/ $\$ 4.50$

Zook, Paul D. (ed.). Economic development and international trade. 382.082/59-15696/ $\$ 3.00$

Schramm, Wilbur L. (ed.) Mass communications. 2d. ed. Univ. of Ill. 384.082/60-8343/ $\$ 6.50$

Locklin, David P. Economics of transportation. 5th ed. R. D. Irwin. 385.13/60-11752/ $\$ 10.65$

Cunnington, Cecil W. A picture history of English costume. Macmillan. 391.0942/60$4684 / \$ 7.00$

Valeton, Elsa M. Dutch costumes. Heinman. 391.09492/60-1681/ $\$ 5.00$

Gennep, Arnold Van. The rites of passage. Univ. Chicago. 392/59-14321/ $\$ 4.50$

Henriques, Fernando. Love in action, the sociology of sex. Dutton. 392.6/60-12295/ $\$ 5.95$

Reiss, Ira L. Premarital sexual standards in America. Free Press. 392.6/60-7095/ $\$ 4.95$ 
Tallman, Marjorie. Dictionary of American folklore. Phil. Lib. 398.0973/60-256/\$5.00

\section{LANGUAGES}

Huebener, Theodore. Audio-visual techniques, in teaching foreign languages. Univ. Pr. 407/60-14320/\$3.25

Delavenay, Emile. An introduction to machine translation. Praeger. 410.28/60$11503 / \$ 4.75$

Art Directors Club of New York. Symbology. Hastings House. 419/59-13554/\$6.95

Carrell, James. Phonetics: Theory and application to speech improvement. McGrawHill. 421.5/59-11926/ $\$ 7.75$

West, Robert W. Phonetics. Rev. ed. Harper. $421.5 / 60-7010 / \$ 6.00$

Ziff, Paul. Semantic analysis. Cornell Univ. $422 / 60-50079 / \$ 5.00$

Wentworth, HaRold. Dictionary of American slang. Crowell. 427.09/60-6237/ $\$ 7.50$

KRAPP, GEORGE P. The English language in America. 2 v. Ungar. 427.97/60-9103/\$12.00

CASE, KeIth E. Mature reading and thinking. Burgess. 428.4/59-15104/ $\$ 3.95$

Elcock, W. D. The Romance languages. Macmillan. 479.109/60-50042/ $\$ 8.50$

\section{SCIENCE}

Allen, Donald S. Physical science. Van Nostrand. 500/60-11058/\$8.25

AsHFORd, THEODORE. From atoms to stars. Holt. 500/60-11234/ $\$ 8.50$

Asimov, IsaAc. The intelligent man's guide to science. 2 v. Basic Books. 500/60-13145/ $\$ 15.00$

Madden, Edward H. The structure of scientific thought. Houghton. 501/60-16020/ $\$ 5.00$

MCGraw-Hill encyclopedia of science and technology. 15 v. McGraw-Hill. 503/60$11000 / \$ 175.00$

SCIEnCE Survey, v. 1 Macmillan. 504/60-4677/ $\$ 5.75$

Russell, Bertrand $R$. The future of science. Philosophical Library. 508.1/60-150/\$2.75

Bluemle, ANDREw (ed.). Saturday science. Dutton. 508.2/60-8944/ $\$ 5.95$

SMITHSONIAN InSTITUTION. Smithsonian treasury of science. $3 \mathrm{v}$. Simon \& Schuster. 508.2/ $60-12579 / \$ 15.00$

Altwerger, Samuel I. Modern mathematics. Macmillan. 510/60-5054/\$6.75
Cooke, Nelson M. Basic mathematics for electronics. 2d ed. McGraw-Hill. 510/59$14441 / \$ 7.50$

SACHS, JEROME M. Basic college mathematics. Allyn \& Bacon. 510/60-10799/ $\$ 5.95$

VAnCE, Elbridge P. Fundamentals of mathematics. Addison-Wesley. 510/60-5165/ $\$ 7.50$

International dictionary of applied mathematics. Van Nostrand. 510.3/60-16931/ $\$ 25.00$

Analogue and digital computers. Philosophical Lib. 510.78/60-4976/\$15.00

Ivall, T. E. Electronic computers. $2 \mathrm{~d}$ ed. Philosophical Library. 51 0.78/60-1504/ $\$ 15.00$

Sangren, Ward C. Digital computers and nuclear reactor calculations. Wiley. 510.78/ 60-11728/\$8.50

Scott, Norman R. Analog and digital computer technology. McGraw-Hill. 510.78/60$8843 / \$ 12.75$

Jackson, Albert S. Analog computation. McGraw-Hill. 510.7824/59-11934/\$13.50

LEDLEY, Robert S. Digital computer and control engineering. McGraw-Hill. 510.7834/ $59-15055 / \$ 14.50$

Ralston, Anthony (ed.). Mathematical methods for digital computers. Wiley. 510.$7834 / 60-6509 / \$ 9.00$

Mochel, MYron G. Fundamentals of engineering Graphics. Prentice-Hall. 510.84/60$12247 / \$ 8.50$

Felix, Lucienne. The modern aspect of mathematics. Basic Books. 510.9/60-6780/ $\$ 5.00$

Crowder, Norman A. The arithmetic of computers. Doubleday. 511.1/60-13380/\$3.95

Meier, Robert C. An introduction to mathematics for business analysis. McGraw-Hill. $511.8 / 60-8840 / \$ 6.95$

MinRath, William R. Handbook of business mathematics. Van Nostrand. 511.8/59$15101 / \$ 9.85$

RosenBACH, Joseph B. Intermediate algebra for colleges. 2d ed. Ginn. 512/60-16096/ $\$ 5.00$

Wolter, Kurt. Mathematics refresher. Philosophical Library. 512/60-149/\$3.75

Karlin, Samuel. Mathematical methods and theory in games, programming, and economics. Addison-Wesley. 512.8/60-5402/ $\$ 10.75$

Levi, Howard. Foundations of geometry and trigonometry. Prentice-Hall. 513.01/60$15017 / \$ 10.60$ 
Schwartz, Abraham. Analytic geometry and calculus. Holt. 516/60-11237/ $\$ 9.50$

Schwartz, Manuel. Vector analysis. Harper. $516.83 / 58-13968 / \$ 7.50$

Johnson, Richard E. Calculus, with analytic geometry. Allyn \& Bacon. 517/59-10051/ $\$ 8.75$

LI, Wen-HSIUng. Engineering analysis. Van Nostrand. 517/60-12245/\$11.00

Thomas, George B. Calculus and analytic geometry. 3rd ed. Addison-Wesley. 517/60$5015 / \$ 9.75$

Kent, James R. Differential and integral calculus. Houghton. 517.1/60-1035/\$6.75

Forsyth, ANDREw R. Theory of differential equations. $6 \mathrm{v}$. in 3. Dover. $517.38 / 60-747 /$ $\$ 16.00$

Olmstead, John M. H. Real variables. Appleton. 517.52/60-5076/ $\$ 9.00$

Goldberg, Samuel. Probability. PrenticeHall, 519.1/60-10871/\$7.95

BRUNK, H. D. An introduction to mathematical statistics. Ginn. 519.9/60-1582/\$7.00

Chorafas, Dimitris N. Statistical processes and reliability engineering. Van Nostrand. 519.9/60-14786/\$12.75

Harman, Harry $\mathrm{H}$. Modern factor analysis. Univ. of Chicago. 519.9/60-11591/\$10.00

FinNey, David J. An introduction to the theory of experimental design. Univ. of Chicago. 519.92/60-8126/\$7.00

SiIAPLEY, Harlow (ed.). Source book in astronomy, 1900-1950. Harvard Univ. $520.82 / 60-13294 / \$ 10.00$

Hoyle, Fred. The nature of the universe. Rev. ed. Harper. 523/60-13436/\$3.00

RichaRdSON, ROBERT S. The fascinating world of astronomy. McGraw-Hill. 523/60-6981/ $\$ 5.95$

Whitrow, G. I. The structure and evolution of the universe. Rev. ed. Hillary House. $523.1 / 59-3090 / \$ 4.50$

Brown, Lloyd A. Map making. Little, Brown. $526.8 / 60-9338 / \$ 4.75$

Smith, Robert A. Semiconductors. Cambridge Univ. 527.622/59-16973/ $\$ 12.50$

Gamow, George A. Physics: foundations and frontiers. Prentice-Hall. 530/60-12209/ $\$ 7.95$

Resnick, Robert. Physics for students of science and engineering. $2 \mathrm{v}$. Wiley. 530/60$6455 / \$ 6.00$

Richards, James A. Modern University physics. Addison-Wesley. 530/60-8246/ $\$ 10.75$

Fritz, Eugene. Energies of the universe. Philosophical Lib. 530.1/60-16278/\$4.75
Massey, Sir Harrie. The new age in physics. Harper. 530.9/60-10427/ $\$ 5.00$

INGARD, UNO. Introduction to mechanics, matter and waves. Addison-Wesley. 531/60$8337 / \$ 9.75$

Stephenson, Reginald J. Mechanics and properties of matter. 2d ed. Wiley. 531.017/ $60-10326 / \$ 7.50$

Shames, Irving H. Engineering mechanics: statistics and dynamics. Prentice-Hall. 531. $2 / 60-8509 / \$ 9.75$

Albertson, Maurice L. Fluid mechanics for engineers. Prentice-Hall. 532/60-14182/ $\$ 13.00$

Pugit, Emerson M. Principles of electricity and magnetism. Addison-Wesley. 537/60 $8245 / \$ 8.75$

Adler, Richard B. Electromagnetic energy transmission and radiation. Wiley. 537.1/ 60-10305/\$14.50

FANo, Robert M. Electromagnetic fields, energy, and forces. Wiley. 537.1/60-6453/ $\$ 12.00$

Daly, James. Basic electronics. Macmillan. 537.5/59-16963/ $\$ 9.00$

Evans, Walter H. Experiments in electronics. Prentice-Hall. 537.5072/59-14245/\$6.95

Ellis, R. Hobart. Nuclear technology for engineers. McGraw-Hill. 539.7/59-13201/ $\$ 9.50$

Jacobs, Alan M. Basic principles of nuclear science and reactors. Van Nostrand. 539.7/ $60-11060 / \$ 6.50$

LETTENMEYER, LORE. Dictionary of atomic terminology. Philosophical Lib. 539.703/ $59-65415 / \$ 6.00$

Nuclear spectroscopy, ed. by Fay A jzenberg. Selove. 2 v. Academic Press. 539.74/59. $7675 / \$ 16.00$ ea.

Hiller, Lejaren A. Principles of chemistry. McGraw-Hill. 540/59-15465/\$7.75

Laitinen, Herbert A. Chemical analysis. McGraw-Hill. 545/59-9991/ $\$ 12.50$

KLEINBERG, JАCOB. Inorganic chemistry. Heath. 546/60-5284/\$10.75

Day, Allan R. Organic chemistry. Van Nostrand. 547/60-11062/\$9.50

Ball, H. W. Minerals and rocks. Hanover House. 549.084/60-1186/\$4.95

Gleason, Sterling. Ultraviolet guide to minerals. Van Nostrand. 549.12/60-16925/\$6.95

Emmons, William H. Geology. 5th ed. McGraw-Hill. 550/60-8024/\$7.95

Namowitz, Samuel N. Earth Science. 2d ed Van Nostrand. 551/59-15103/\$5.20 
Sparks, B. W. Geomorphology. Longmans. $551.4 / 60-4033 / \$ 7.75$

Cowen, Robert C. Frontiers of the sea. Doubleday. 551.46/60-8859/ $\$ 4.95$

Glossary of meteorology. American Meteorological Society. 551.503/59-65380/\$12.00

DunN, Gordon E. Atlantic hurricanes. Louisiana State Univ. 551.552/60-10630/\$10.00

Weller, James M. Stratigraphic principles and practice. Harper. 551.7/59-13924/ $\$ 10.00$

Stokes, William L. Essentials of earth history. Prentice-Hall. 551.7/60-12213/\$8.75

Clark, Thomas H. The geological evolution of North America. Ronald Press. 551.7097/ $60-6154 / \$ 7.50$

Smales, A. A. (ed.) Methods in geochemistry. Interscience. 551.9/60-12904/ $\$ 13.50$

Beerbower, James R. Search for the past. Prentice-Hall. 560/60-5040/ $\$ 7.50$

Easton, William H. Invertebrate paleontology. Harper. 562/59-13921/ $\$ 10.00$

Forde-Johnston, James L. Neolithic cultures of North Africa. Humanities. 571.20961/ $60-2536 / \$ 7.50$

Graziosi, Paolo. Palaeolithic art. McGrawHill. 571.7/59-13435/\$35.00

Birket-Smith, Ka J. Primitive man and his ways. International Pub. 572/60-4838/ $\$ 6.25$

Goldschmidt, Walter R. (ed.). Exploring the ways of mankind. Holt. 572.082/60$7797 / \$ 6.50$

Kephart, Calvin. Races of mankind. Philosophical Lib. 572.9/60-13647/\$6.00

Otrenberg, Simon (ed.). Cultures and societies of Africa. Random House. 572.96/ $60-6194 / \$ 7.50$

Ruud, Jorgen. Taboo. N. Y., Humanities. $572.9691 / 60-2537 / \$ 7.50$

Montagu, M. F. Ashleey. An introduction to physical anthropology. 3d ed. Thomas. 573/59-14204/\$14.50

Desrosier, Norman W. Radiation technology in food, agriculture, and biology. Avi. $574.19 / 60-4275 / \$ 12.50$

OncLEY, John L. (ed.). Biophysical science. Wiley. 574.191/59-10786/\$6.50

Swanson, Carl P. The cell. Prentice-Hall. $574.87 / 60-8511 / \$ 2.95$

Willmer, Edward N. Cytology and evolution. Academic. 574.87/60-7864/\$10.00

Burns, William A. (ed.). The natural history of the Southwest. F. Watts. 574.979/59. $7072 / \$ 4.95$

Douglas, William O. My wilderness: the
Pacific: West. Doubleday. 574.9795/60 $13519 / \$ 4.95$

KerKut, G. A. Implications of evolution. Pergamon. 575/60-9644/ $\$ 5.00$

Begg, Charles M. An introduction to genetics. Macmillan. 575.1/60-2392/ $\$ 6.00$

Stern, Curt. Principles of human genetics 2d ed. W. H. Freeman. 575.1/60-12098/ $\$ 9.50$

TAx, Sol. Evolution after Darwin. 3 v. Univ. of Chicago. 575.3/60-10575/ $\$ 25.00$

JaCOBS, MORRIS B. Handbook of microbiology. Van Nostrand. 576/60-15811/ $\$ 8.50$

International symposium on the origin of life on the earth, Moscow, 1957. Proceedings. Pergamon. 577/59-12060/\$15.00

MacIver, Rober' M. Life: its dimensions and its bounds. Harper. 577/60-10412/ $\$ 3.00$

Hill, John B. Botany. (3rd ed.). McGrawHill, 581/60-6972/ $\$ 8.95$

MEYer, Bernard S. Introduction to plant physiology. Van Nostrand. 581.1/60-9034/ $\$ 7.50$

Polunin, Nicholas V. Introduction to plant geography and some related sciences. McGraw-Hill. 581.9/60-50391/ $\$ 10.00$

Abrams, LeRoy. Illustrated flora of the $\mathrm{Pa}$ cific states. v. 4. Stanford Univ. 581.979/239934/ $\$ 17.50$

ANDERSON, JACOB P. Flora of Alaska and adjacent parts of Canada. Iowa State Univ. 581.9798/59-15232/\$8.50

PorTer, CEDric I. Taxonomy of flowering plants. W. H. Freeman. 582.13012/59$11828 / \$ 6.75$

Schwarzenbach, Hans. Flowers in color. Viking. 582.13084/60-51615/\$20.00

McCurrach, James C. Palms of the world. Harper. 584.5/60-5968/ $\$ 17.50$

Moore, Alma. The grasses. Macmillan. $584.9 / 60-5085 / \$ 5.00$

Fink, Bruce. The lichen flora of the United States. Univ. of Mich. 589.10973/60-63331/ $\$ 12.50$

Braungari, Dale C. An introduction to animal biology. 5th ed. Mosby. 591/60-5856/ $\$ 6.25$

Eaton, Theodore H. Comparative anatomy of the vertebrates. Harper. 591.4/59-13915/ $\$ 6.00$

MiLne, Lorus J. The balance of nature. Knopf. 591.5/60-13433/\$5.00

Nicol, Joseph A. C. The biology of marine animals. Interscience. 591.92/60-1839/ $\$ 14.60$ 
Jacobs, Jake. Marineland diver. Dodd, Mead. 591.9266/60-9655/\$4.00

Buchsbaum, Ralph M. The lower animals: living invertebrates of the world. Doubleday. 592/60-10650/\$12.50

Allan, Joyce. Australian shells. C. T. Branford. 594.0994/60-96/ $\$ 12.00$

Allan, Joyce. Cowry shells of the world seas. Branford. 594.329/\$12.00

Gosline, William A. Handbook of Hawaiian fishes. Univ. of Hawaii. 597.09969/58$11692 / \$ 11.00$

Mertens, Robert. The world of amphibians and reptiles. McGraw-Hill. 598.1/60-16347/ $\$ 15.00$

Delacour, Jean T. The waterfowl of the world. 3 v. W. S. Heinman. 598.2/55-600/ $\$ 25.00$

Booth, Ernest S. Birds of the West, including Alaska, Western Canada and Hawaii. 3d ed. Calif. Outdoor Pictures. 598.2978/ $60-16322 / \$ 5.00$

Clark, Sir Wilfred E. The antecedents of man. Quadrangle Books. 599.8/60-8710/ $\$ 6.00$

\section{APPLIED SCIENCE}

Brink, RichaRd E. An outline of U. S. patent law. Interscience. 608.7/59-15769/\$7.50

Windle, William F. Textbook of histology. 3rd ed. McGraw-Hill. 611.018/60-11968/ $\$ 10.95$

Gardner, Ernest D. Anatomy. Saunders. $611.082 / 60-5419 / \$ 15.00$

Miller, Benjamin F. Man and his body. Simon \& Schuster. 612/60-10993/ $\$ 5.95$

Hanrahan, James S. Space biology. Basic Books. 612.01449/60-12021 $/ \$ 6.00$

World review of nutrition and dietetics. v. 1 Lippincott. 612.3082/59-13480/\$12.00

Handbook of aging and the individual. Univ. of Chicago. 612.67082/59-12106/\$12.50

Diehl, Harold S. Textbook of healthful living. 6th ed. McGraw-Hill. 613/59-13200/ $\$ 6.75$

Adams, Leon D. The commonsense book of drinking. D. McKay. 613.8/60-7113/\$3.95

Lolli, Giorgio. Social drinking. World. $613.8 / 60-6687 / \$ 4.50$

Roueche, Berton. The neutal spirit. Little. 613.8/60-11640/\$3.50

Freeman, Ruth B. Administration of public health services. Saunders. 614/60-7455/ $\$ 6.75$
Smith, Ralph L. The health hucksters. Crowell. 614.3/60-15098/ $\$ 3.95$

Moodie, William. Hypnosis in treatment. Emerson Books. 615.8512/60-15745/ $\$ 4.00$

Barbara, Dominick A. (ed.). Psychological and psychiatric aspects of speech and hearing. Thomas. $616.855 / 60-9307 / \$ 19.50$

Murphy, Albert T. Stuttering and personality dynamics. Ronald. 616.8554/60-14180/ $\$ 6.50$

Smith, Jackson A. Psychiatry. Williams \& Wilkins. 616.89/60-5772/ $\$ 7.00$

Hinsie, Leland E. Psychiatric dictionary. 3rd ed. Oxford Univ. 616.8903/60-5101/\$17.50

Rutledge, James $H$. The home encyclopedia of modern surgery. Chilton. 617.024/60$8821 / \$ 12.50$

Mitchell, Robert M. Nine months to go. Lippincott. 618.2/60-7846/\$3.95

SCHNECK, JEROME M. A history of psychiatry. Thomas. 618.8909/59-14209/ $\$ 5.50$

Roth, Arthur. The teen-age years. Doubleday. $618.9 / 60-6906 / \$ 3.95$

LitchField, HaRry R. Your child's care. Rev. ed. Doubleday. 618.92/60-11385/\$3.95

JOHNSON, LEE H. Engineering: principles and problems. McGraw-Hill. 620/60-9845 $\$$ \$5.50

Rogers, A. E. Analog computation in engineering design. McGraw-Hill. 620/59$10722 / \$ 16.00$

Baer, Charles J. Electrical and electronic drawing. McGraw-Hill. 621.3004/59-11920/ $\$ 6.00$

WALSH, JoHN B. Introductory electric circuits. McGraw-Hill. 621.31921/59-15069/ $\$ 8.50$

McPartland, Joseph F. Electrical design details. McGraw-Hill. 621.3282/59-I5468/ $\$ 8.50$

Stout, Melville B. Basic electrical measurements. 2d ed. Prentice-Hall, 621.37/60$15089 / \$ 11.65$

Cooke, Nelson M. Electronics and nucleonics dictionary. McGraw-Hill. 621.381/60$10605 / \$ 12.00$

Grob, Bernard. Application of electronics McGraw-Hill. 621.381/59-14448/ $\$ 7.00$

Mande, Matthew. Fundamentals of electronics. Prentice-Hall. 621.381/60-7339/ $\$ 10.60$

Markus, John. Handbook of electronic control circuits. McGraw-Hill. 621.3815/59$13208 / \$ 8.50$

Mason, Samuel J. Electronic circuits, signals and systems. Wiley. 621.3815/60-5601/ $\$ 12.50$

RIDFR, JoHn F. Encyclopedia on cathode ray 
oscilloscopes and their uses. Rider. 621. $38151 / 59-15917 / \$ 21.95$

Crowhurst, Norman H. The stereo high fidelity handbook. Crown. 621.3818/59$14024 / \$ 5.95$

Radio and television engineers' reference book. 3d ed. Newnes. 621.384/60-2770/ $\$ 25.00$

Bernstein, Julian L. Video tape recording. John F. Rider. 621.388/60-8960/\$8.95

Mills, Mark M. Modern nuclear technology McGraw-Hill. 621.48082/59-15058/\$9.50

Porter, Harold W. Machine shop operations and setups. 2d ed. Amer. Tech. Society. $621.75 / 60-7605 / \$ 5.50$

Hunt, Kenneth H. Mechanisms and motion. Wiley. 621.81/59-65391/ $\$ 4.25$

Maxwell, Robert L. Kinematics and dynamics of machinery. Prentice-Hall. 621.81/ $60-12246 / \$ 9.75$

OrdWAY, Frederick I. International missile and spacecraft guide. McGraw-Hill. 623.4513/59-14463/ $\$ 25.00$

BAar, James. Polaris. Harcourt. 623.4519/60$12731 / \$ 4.50$

U. S. Air Force. Air Training Command. Fundamentals of guided missiles. Aero. 623.4519/59-14965/ $\$ 12.50$

MEDARIS, John B. Countdown for decision. Putnam. 623.7/60-13671 $/ \$ 5.00$

Gantz, Kenneth F. (ed.). Nuclear flight. Duell. 623.746/60-9572/ $\$ 4.00$

Lytel, Allan H. Marine radio and electronics. Cornell Maritime. 623.864/60-14390/ $\$ 7.00$

Nicholl, George William R. Survival at sea. DeGraff. $623.865 / 60-16239 / \$ 6.00$

SEELYe, ElwYN E. Data book for civil engineers. v. 1 3d ed. Wiley. 624.02/57-5932/ $\$ 24.00$

Condit, Carl W. American building art. Oxford Univ. 624.0973/59-11752/\$12.50

SPANGler, Merlin G. Soil engineering. $2 \mathrm{~d}$ ed. International Textbook. 624.151/60-9019/ $\$ 9.75$

Carpenter, Samuel T. Structural mechanics. Wiley. 624.17/60-6448/ $\$ 9.50$

NAYLER, JOSEPH L. Dictionary of aeronautical engineering. Philosophical Lib. 629.$1303 / 59-4976 / \$ 10.00$

Bernardo, James V. Aviation in the modern world. Dutton. 629.1309/59-5824/ $\$ 5.95$

Gibbs-Smith, Charles H. The aeroplane. British Information Services. 629.1309/60$4248 / \$ 6.50$
Nielsen, Jack N. Missile aerodynamics. McGraw-Hill. 629.1323/59-14462/\$12.50

Besserer, C. W. Guide to the space age. Prentice-Hall. 629.1388/59-15719/\$7.95

DUbRIDGE, LeE A. Introduction to space. Columbia Univ. $629.1388 / 60-8186 / \$ 2.50$

Ehricke, Krafft A. Space flight. Van Nostrand. 629.1399/60-7478/\$14.50

Lauer, Alvhr R. The psychology of driving. Charles C. Thomas. 629.28/59-14929/ $\$ 10.50$

Gaynor, Frank. Aerospace dictionary. Philosophical Lib. 629.403/60-16202/\$6.00

Symposium on Space Physics, Wash., D. C., 1959. The exploration of space. Macmillan. $629.4082 / 60-10053 / \$ 5.50$

Wiech, Raymond E. Fundamentals of rocket propulsion. Reinhold. 629.42/60-10508/ $\$ 5.50$

Caidin, Martin. The astronauts. Dutton. $629.45 / 60-12113 / \$ 3.95$

Von Braun, Wernher. First men to the moon. Holt. 629.454/60-5202/ $\$ 3.95$

BIBBERO, ROBERT J. Dictionary of automatic control. Reinhold. 629.803/60-14156/\$6.00

Wilts, Charles H. Principles of feedback control. Addison-Wesley. 629.83/60-11854/ $\$ 8.75$

Allen, Shirley W. An introduction to American forestry. 3d ed. McGraw-Hill. 634.90973/60-6956/ $\$ 7.95$

New illustrated encyclopedia of gardening. Graystone Press. 635.903/60-7000/ $\$ 49.50$

Oshikawa, Josui. Manual of Japanese flower arrangement. International. $635.9663 / 60$ $4862 / \$ 12.50$

Beale, James H. The evergreens. Doubleday. $635.977 / 59-12024 / \$ 4.50$

Summerhays, Reginald S. Encyclopedia for horsemen. F. Warne. 636.103/59-65201/ $\$ 5.00$

Meyer, Lillian. Food chemistry. Reinhold. $641.1 / 60-11080 / \$ 8.10$

Conil, Jean. Gastronomic tour de France. Dutton. 641.5944/60-337/ $\$ 7.95$

Schulke, Zelda W. Holiday and party table settings. Hearthside. 642.7/60-12960/\$4.50

SchutTe, William M. Communication in business and industry. Holt. 651.7/60-6403/ $\$ 6.50$

Wilkinson, Clyde W. (ed.). Writing for business. 3d ed. R. D. Irwin. 651.74/60-12921/ $\$ 6.00$

Glaistfr, Groffrey A. An encyclopedia of the book. World. $655.03 / 60-6660 / \$ 17.50$

Morison, Stanley. Four centuries of fine 
printing. 4th ed. Barnes \& Noble. 655.24/ $60-3397 / \$ 3.95$

Pilpel, Harriet F. A copyright guide. Bowker. 655.673/60-9559/ $\$ 2.00$

Childs, Wm. Herbert. Accounting for management control. Simmons-Boardman. 657/ $60-10787 / \$ 7.75$

Milroy, Robert R. Accounting theory and practice, intermediate. Houghton Mifflin. $657 / 60-16275 / \$ 7.95$

Vance, Lawrence L. Accounting: principles and control. Holt. $657 / 60-7101 / \$ 7.50$

Anderson, Richard C. Management practices. McGraw-Hill. 658/60-8014/ $\$ 7.00$

Hurley, Morris E. Business administration. 2d ed. Prentice- Hall. 658/60-10157/\$7.95

Jucius, Michael J. Elements of managerial action. R. D. Irwin. 658/60-13238/ $\$ 9.00$

Peckham, Morsf. Humanistic education for business executives. Univ. of Penn. 658/ $60-9884 / \$ 4.50$

PfiffNer, John M. Administrative organization. Prentice-Hall. 658/60-10778/\$9.00

Rubenstein, Albert H. Some theories of organization. Dorsey. 658/60-14052/ $\$ 10.60$

SPRiegel, William R. Principles of business organization and operation. 3d ed. Prentice-Hall. 658/60-8485/ $\$ 10.60$

Voris, William. The management of production. Ronald. 658/60-7768/\$6.50

Garvin, Walter W. Introduction to linear programming. McGraw-Hill. 658.018/60$8025 / \$ 8.75$

Flagle, Charles D. (ed.). Operations research and systems engineering. Johns Hopkins. 658.072/60-8280/\$14.50

LAsSER, JACOB K. (ed.) Business management handbook. 2d ed. McGraw-Hill. 658.082/ $69-15466 / \$ 12.50$

ANTHONy, RoBert N. Management accounting. Rev. ed. R. D. Irwin. 658.15/60-14049/ $\$ 10.00$

Smith, Charles A. Financial and administrative accounting. 2d ed. McGraw-Hill. 658. $15 / 59-15473 / \$ 8.50$

FAYERWEATHER, JoHN. Management of international operations. McGraw-Hill. 658.16/ 59-1 3931/ $\$ 9.50$

Hugh-Jones, Edward M. (ed.). Human relations and modern management. Quadrangle Books. 658.3/59-15786/ $\$ 6.00$

Strauss, George. Personnel: the human problems of management. Prentice-Hall. $658.3 / 60-12214 / \$ 10.00$

De Phillips, Frank A. Management of train- ing programs. R. D. Irwin. 658.386/60$14053 / \$ 9.00$

Heyel, Carl (ed.). Handbook of industrial research management. Reinhold. 658.57/ $59-15717 / \$ 12.00$

Herdeg, Walter (ed.). Packaging. Praeger. 658.7884/A60-2243/\$17.50

Packaging and display encyclopaedia. Newnes. 658.7884/60-163/ $\$ 21.00$

Meloan, Taylor W. (ed.). Selling. Macmillan. 658.8082/60-9956/\$7.50

Phelps, Dudley M. Marketing management. Rev. ed. Irwin. 658.81/60-15376/\$10.60

Friedman, WaLter F. Industrial packaging. Wiley. 658.83/60-5599/\$11.50

Shaw, Steven J. (ed.). Salesmanship. Holt. 658.85082/60-8596/ $\$ 5.75$

Brown, Paul L. Retailing management. 2d ed. Ronald. $658.87 / 60-7614 / \$ 8.00$

AMIRICAN BANKIRs Association. Bank installment credit collection and accounting. Amer. Bankers Assn. 658.883/59-3356/ $\$ 2.50$

Burton, Philip W. The profitable science of making media work. Printers' Ink Books. $659.1 / 59-2556 / \$ 8.50$

Dirksen, Charles J. Advertising principles and problems. R. D. Irwin. 659.1/60-6711/ $\$ 9.65$

Golden, Hal. How to plan, produce, and publicize special events. Oceana. 659.111/ $60-7355 / \$ 6.00$

Advertising directions: trends in visual advertising. Art Directions. 659.13/59-14827/ $\$ 10.00$

Cardamone, Tom. Advertising agency \& studio skills. Watson-Guptill. 659.1324/59. $15387 / \$ 4.75$

Leach, Mortimer. Letter design in the graphic arts. Reinhold. 659.1324/60-11009/ $\$ 12.00$

Mantell, Cunarles L. Electrochemical engineering. McGraw-Hill. 660.297/59-13207/ $\$ 16.50$

Hyams, Edward S. The wine country of France. Lippincott. 663.20944/60-12215/ $\$ 4.50$

Reeve, Lloyd E. Gift of the grape. S. F. Filmer. 663.22/59-10056/ $\$ 5.00$

Society of the Plastics Industry. Plastics engineering handbook. 3d ed. Reinhold. 668. $41 / 60-8081 / \$ 15.00$

Aitchison, Leslie. A history of metals. $2 \mathrm{v}$. Interscience. $669.09 / 60-3041 / \$ 30.00$ 
Smith, Cyril S. A history of metallography. Univ. of Chicago. 669.95/60-7243/\$8.50

SCHALler, Gilbert S. Engineering manufacturing methods. 2d ed. McGraw-Hill. 67l/ $59-8561 / \$ 9.50$

Stout, Evelyn E. Introduction to textiles. Wiley. 677/60-14717/ $\$ 6.50$

Mix, Floyd M. (ed.). Practical carpentry. new ed. Goodheart-Wilcox Co. 694/60-6021/ $\$ 5.00$

Porges, JoHN. Handbook of heating, ventilating and air conditioning. 4th ed. Newnes. $697.083 / 60-2729 / \$ 7.50$

\section{FINE AR'IS}

Guggenheimer, Richard H. Creative vision for art and for life. Rev. ed. Harper. 701/ $60-11496 / \$ 3.50$

Malraux, Andre. The metamorphosis of the gods. Doubleday. 701.1/60-10395/ $\$ 20.00$

Maritain, Jacques. The responsibility of the artist. Scribner. 701.1 /60-6331 $/ \$ 2.95$

Gombrich, Ernst H. Art and illusion. Pantheon. $701.15 / 59-13517 / \$ 10.00$

Encyclopedia of world art. $15 \mathrm{v}$. (2 v. pub. so far) McGraw-Hill. 703/59-13433/ $\$ 480.00$

Hayward, Helena. (ed.). The connoisseur's handbook of antique collecting. Hawthorn. $703 / 60-8797 / \$ 5.95$

Roditi, Edouard. Dialogues on art. Humanities. 704/60-4000/ $\$ 6.00$

Huxley, Aldous L. On art and artists. Harper. 704.9/60-10408/\$3.95

L'oeil. Modern art yesterday and tomorrow. The Selective Eye IV. Reynal. 704.92/55$11347 / \$ 10.00$

MaIson, K. E. Art themes and variations. H. N. Abrams. 704.94/60-15637/ $\$ 17.50$

Selz, Peter. New images of man. Doubleday. 704.942/59-14221/ $\$ 5.00$

The creative arts in American education. Harvard Univ. 707/60-15242/\$2.50

SCHULler, SEPP. Forgers, dealers, experts. Putnam. 708.054/60-13452/\$4.50

Huyghe, Rene. Art treasures of the Louvre. H. N. Abrams. 708.4/60-8496/ $\$ 17.50$

Gardner, Helen. Art through the ages. 4th ed. Harcourt. 709/59-5510/\$6.95

SyPHER, Wylie. Rococo to cubism in art and literature. Random House. 709/60-8373/ $\$ 7.00$

Schonberger, Arno. The rococo age, art and civilization of the 18th century. McGrawHill. 709.033/60-11310/\$23.50
TAPIE, Victor L. The age of grandeur, Baroque art and architecture. Grove. 709.033/ $60-11100 / \$ 12.50$

KePEs, Gyorgy. (ed.). The visual arts today. Wesleyan Univ. 709.04/60-13159/ $\$ 6.00$

Liberman, Alexander. The artist in his studio. Viking. 709.04/60-13244/ $\$ 17.50$

ScHODER, RAYMOND V. Masterpieces of Greek art. Graphic Soc. 709.38/60-8922/\$12.50

Marinatos, Spyridon. Crete and Mycenae. H. N. Abrams. $709.391 / 60-8399 / \$ 25.00$

Berenson, Bernard. The passionate sightseer; from the diaries, 1947 to 1956. Simon \& Schuster. 709.45/60-6799/\$10.00

Morgan, Charles H. The life of Michelangelo. Reynal. 709.45/60-9228/ $\$ 6.00$

Duncan, David D. The Kremlin. Graphic Society. 709.47/60-8919/ $\$ 25.00$

Rice, David T. The art of Byzantium. Abrams. 709.4961/59-11864/ $\$ 25.00$

RACHEWILTz, BORIS DE. Egyptian art. Viking. 709.62/60-11232/\$6.95

LEUZinger, Elsy. Africa; the art of the Negro peoples. McGraw-Hill. 709.67/60-13819/ $\$ 7.95$

Larkin, Oliver W. Art and life in America Rev. and enl. ed. Holt. 709.73/60-6491/ $\$ 10.00$

Mendelowitz, Daniel M. A history of American art. Holt. 709.73/60-10762/ $\$ 8.95$

Smith, Bernard. European vision and the South Pacific, 1768-1850. Oxford Univ. $709.9 / 60-2082 / \$ 13.45$

Rosenau, Helen. The ideal city in its architectural evolution. Book and Art Shop. $711.4094 / 59-3925 / \$ 6.00$

FaUre, Gabriel. Gardens of Rome. Essential Books. 712.0945632/60-50106/ $\$ 8.50$

Sunset. Garden \& patio building book. Lane. $712.62 / 60-9427 / \$ 6.95$

Schwarzenbach, Hans. Decorative trees and shrubs. Viking. 715.084/60-2519/\$20.00

Fitch, James M. Walter Gropius. G. Braziller. $7220.943 / 60-13308 / \$ 4.95$

Von Eckhardt, Wolf. Eric Mendelsohn. G. Braziller. 720.943/60-14514/ $\$ 4.95$

Huxtable, Ada L. Pier Luigi Nervi. G. Braziller. 720.945/60-6076/\$3.95

Pica, Agnoldomenico. Recent Italian architecture. W. S. Heinman. 720.954/60-1742/ $\$ 5.50$

Collins, George R. Antonio Gaudi. Braziller. $720.946 / 60-6078 / \$ 3.95$

Guthfim, Frederick A. Alvar Aalto. Braziller. $720.9471 / 60-6080 / \$ 3.95$ 
Choay, Francoise. Le Corbusier. Braziller. $720.9494 / 60-6097 / \$ 3.95$

ANDREws, Wayne. Architecture in America. Atheneum. 720.973/60-7783/ $\$ 15.00$

Bush-Brown, Albert. Louis Sullivan. G. Braziller. 720.973/60-13306 $/ \$ 4.95$

Drexler, Arthur. Ludwig Mies van der Rohe. G. Braziller. 720.973/60-6077 $/ \$ 3.95$

McCoy, Esther. Richard Neutra. G. Braziller. $720.973 / 60-51015 / \$ 4.95$

Mumford, Lewis. (ed.). Roots of contemporary American architecture. Grove. 720. 973/59-14138/ $\$ 6.00$

Scully, Vincent J., JR. Frank Lloyd Wright. G. Braziller. 720.973/60-6075/ $\$ 3.95$

Wright, Frank Lloyd. Writings and buildings. Horizon. 720.973/60-8 I66/ $\$ 3.95$

Wright, Olgivanna L. The shining brow: Frank Lloyd Wright. Horizon. 720.973/ $60-9252 / \$ 4.50$

Papadaki, Stamo. Oscar Niemeyer. G. Braziller. $720.981 / 60-13307 / \$ 4.95$

Reidy, AfFonso E. The works of Affonso Eduardo Reidy. Praeger. 720.981/60-6997/ $\$ 11.50$

Boethius, Axel. The golden house of Nero; some aspects of Roman architecture. Univ. of Michigan. 722.7/57-9137/ $\$ 15.00$

Brake, Peter. The master builders. Knopf. $724.9 / 60-10276 / \$ 6.50$

Louis-Frederic, pseud. The art of India. H. N. Abrams. 726.10954/59-12873/\$17.50

Architegtural Record. The second treasury of contemporary houses. F. W. Dodge Corp. 728.084/59-14353/\$7.75

Coffin, David R. The Villa d'Este at Tivoli. Princeton Univ. 728.84094563/60-5744/ $\$ 17.50$

UNESCO. Israel: ancient mosaics. Graphic Society. $729.7095694 / 60-4113 / \$ 18.00$

UNESCO. Greece: Byzantine mosaics. New York Graphic Society. 792.72/60-1214/ $\$ 18.00$

Berckelaers, Ferdinand L. The sculpture of of this century. G. Braziller. 730.904/60$7807 / \$ 15.00$

Grohmann, Will. The art of Henry Moore. H. N. Abrams. 730. 942/60-7798/ $\$ 15.00$

Watson, William. Sculpture of Japan, from the fifth to the fifteenth century. Viking. $730.952 / 60-910 / \$ 15.00$

EsPINOSA, JosE E. Saints in the valleys. Univ. of New Mexico. 730.979/60-5656/\$6.50

Haggar, Reginald G. The concise encyclopedia of continental pottery and porcelain.
Hawthorn Books. 738.37/60-10340/\$20.00

Hughes, George B. Victorian pottery and porcelain. Macmillan. 738.37/60-930/\$10.50

LiVERANI, GiUSEPPE. Five centuries of Italian majolica. McGraw-Hill. 738.37/59-13206/ $\$ 28.50$

Okuda, Seirchi (ed.). Japanese ceramics. Tuttle. $738.37 / 60-16172 / \$ 12.50$

Соок, R. M. Greek painted pottery. Quadrangle Books. 738.382/59-15809/ $\$ 12.50$

Baerwald, Marcus. The story of jewelry. Abelard-Schuman. 739.27/59-1 1647/\$6.50

Levitan, Eli L. Animation art in the commercial film. Reinhold. 741. 58/60-13163/ $\$ 6.95$

Rodewald, Fred C. Commercial art as a business. Rev. ed. Viking. 741.6/60-9776/ $\$ 4.95$

Annual of advertising and editorial art and design, 38. Straus and Cudahy. 741.605/22$5058 / \$ 15.00$

Busse, Fritz. San Francisco. Arts Inc. 741. 943/59-14136/\$3.50

Grosz, George. George Grosz. Arts, Inc. 741. 943/59-15105/\$12.50

Klee, Paul. Paul Klee drawings. H. N. Abrams. $741.943 / 60-11598 / \$ 15.00$

Cordier, Daniel. The drawings of Jean Dubuffet. G. Braziller. 741.944/60-14515/ $\$ 15.00$

Cuevas, Jose L. The worlds of Kafka and Cuevas. Falcon. 741.972/59-15413/ $\$ 7.50$

French, Thomas E. Fundamentals of engineering drawings. McGraw-Hill. 744.422/ $59-15459 / \$ 7.50$

Halse, Albert O. Architectural rendering. F. W. Dodge. 744.424/59-8313/\$15.75

Hornung, William J. Architectural drafting. Prentice-Hall. 744.4224/60-6116/\$7.35

Thomas, T. A. Technical illustration. McGraw-Hill. 744.429/60-6986/\$6.50

Toschi, Paolo. Arte popolare italiana. Roma, Carlo Bestetti. Wittenborn Dist. 745.0945/A60-2447/\$27.50

Trowell, Kathleen M. African design. Praeger. $745.44967 / 60-11832 / \$ 7.50$

Hils, Karl. Crafts for all. C. T. Branford. $745.5 / 60-815 / \$ 5.95$

Lewis, Griselda (ed.). Handbook of crafts. Branford. 745.5/60-50564/ $\$ 6.95$

Reed, Carl. Art from scrap. Davis. 745.5/60. 9507/ $\$ 3.95$

Petersen, Grete. Creative leathercraft. Sterling. $745.53 / 60-10378 / \$ 2.95$

Mattson, Elmer B. Creative metalworking. Bruce. $745.56 / 60-3825 / \$ 3.25$

COLLEGE AND RESEARCH LIBRARIES 
Thomas, Richard. Metal smithing for the artist-craftsman. Chilton. 745.56/60-14633/ $\$ 7.50$

Ball, Victoria (Kloss). The art of interior design. Macmillan. 747/60-5407/\$8.50

House \& Garden. Complete guide to interior decoration. 6th ed. Simon \& Schuster. 747/ $60-51353 / \$ 12.95$

Armitage, Edward L. Stained glass. C. T. Branford. 748.5/59-13895/\$15.00

BAKER, JoHN. English stained glass. Harry N. Abrams. 748.5942/60-10886/\$25.00

Bogre, Louise Ade. The complete guide to furniture styles. Scribner. 749.2/59-6239/ $\$ 15.00$

London. National Gallery. The National Gallery. H. N. Abrams. 750.74/60-8400/ $\$ 7.50$

Taubes, Frederic. The art \& technique of landscape painting. Watson-Guptill. $751.45 / 60-8414 / \$ 5.50$

Maiuri, Amedeo. Pompeian wall paintings. Taplinger. 751.7309377/60-4013/\$2.00

Apollonia, Umbro. Fauves and cubists. Crown. 754.06/60-50355/ $\$ 7.95$

Sterling, Charles. Still life painting from antiquity to the present time. Universe Books. 758.4/59-13045/ $\$ 17.50$

Cogniat, Raymond. The century of the impressionists. Crown. 759.05/60-50321/ $\$ 12.50$

Jean, Marcel. The history of surrealist painting. Grove. 759.06/60-11094/\$17.50

Blesh, Rudi. Stuart Davis. Grove. 759.13/59. $13889 / \$ 3.95$

Janis, Harriet. De Kooning. Grove. 759.13/ $59-14402 / \$ 3.95$

Brion, Marcel. Durer, his life and work. Tudor. 759.3/60-50461/ $\$ 5.95$

Marc, Franz. Franz Marc: watercolors, drawings, writings. H. N. Abrams. 759.3/60$11599 / \$ 17.50$

Ponente, Nello. Klee. World. 759.3/60$8729 / \$ 5.75$

SchmidT, Georg. Franz Marc. Crown. 759.3/ $60-4721 / \$ 1.95$

George, Waldemar. Utrillo. Graphic Society. $759.4 / 60-10474 / \$ 10.00$

Manet, Edouard (ed.). Manet. H. N. Abrams. $759.4 / 59-8836 / \$ 27.50$

Nacenta, Raymond. School of Paris; the painters and the artistic climate of Paris since 1910. Graphic Society. 759.4/59-9320/ $\$ 25.00$

Seitz, William C. Claude Monet. H. N. Abrams. 759.4/60-7800/\$15.00
Serullaz, Maurice. The impressionist painters. Universe Books. 759.4/60-12416/ $\$ 10.00$

Traz, Georges DE. French painting. Universe Books. 759.4/60-9527/ $\$ 10.00$

Wrekes, G. P. The invincible Monet. Appleton. $759.4 / 60-13068 / \$ 4.50$

Battisti, Eugenio. Giotto. World. 759.5/60$8730 / \$ 5.75$

Bucheim, Lothar G. Picasso. Viking. 759.6/ $59-16515 / \$ 6.50$

Cowles, Fleur. The case of Salvador Dali. Little, Brown. 759.6/60-5366/\$6.50

Lafuente Ferrai, EnriQue. Velazquez. World. $759.6 / 60-8731 / \$ 5.75$

Picasso, Pablo. Picasso: the early years. Tudor. 759.6/60-50595/ $\$ 7.95$

Tapies Puig, Antonio. Antonio Tapies. G. Wittenborn. 759.6/60-395/ $\$ 7.50$

Ottino Della Chiesa, Angela. Botticelli and his contemporaries. Crown. 759.9/60-50284/ $\$ 7.95$

Clark, Sir Kenneth. Looking at pictures. Holt. 759.94/60-10106/ $\$ 10.00$

Brion, MaRcEL. German painting. Universe Books. 759.943/59-13044/ $\$ 10.00$

Baldass, Ludwig von. Hieronymus Bosch. H. N. Abrams. 759.9492/59-12876/\$18.50

Beckett, Samuel. Bram Van Velde. Grove. $759.9492 / 59-14401 / \$ 3.95$

Wilenski, Reginald H. Flemish painters, 1430-1830. 2 v. Viking. 759.9493/50-1574/ $\$ 37.50$

Chagall, Marc. Lithographs. G. Braziller. 769.944/60-15726/\$25.00

Adams, Andel E. This is the American earth. Knopf. 779.3/60-1364/ $\$ 15.00$

Spaeth, Sigmund G. Fifty years with music. Fleet. $780.072 / 59-8930 / \$ 4.50$

APEL, Willi. The Harvard brief dictionary of music. Harvard Univ. 780.3/60-7986/ $\$ 3.95$

Westrup, Jack A. The new college encyclopedia of music. Norton. 780.3/60-10570/ $\$ 6.95$

Copland, Aaron. Copland on music. Doubleday. $780.8 / 60-15171 / \$ 3.95$

Lang, Paul H. A pictorial history of music. Norton. 780.9/60-6822/ $\$ 10.00$

Pincherle, Marc. An illustrated history of music. Reynal. 780.9/59-65468/\$18.00

VLAD, Roman. Stravinsky. Oxford Univ. $780.92 / 60-50776 / \$ 7.00$

Stock, Dennis. Jazz Street. Doubleday. $781.57 / 59-12629 / \$ 6.95$

Strin, Jack M. Richard Wagner and the syn- 
thesis of the arts. Wayne Univ. 782.1/59$7831 / \$ 5.00$

Hope-Wallace, Philip. A picture history of opera. Macmillan. 782.1084/60-1877/ $\$ 7.00$

Peltz, Mary E. The magic of the opera. Praeger. 782.109.7471/60-901 I $\$ 10.00$

LAWLESS, RAY M. Folksingers and folksongs in America. Duell. 784.4973/60-545 I $\$ 10.00$

Lomax, Allan (ed.). The folk songs of North America. Doubleday. 784.4973/M60-2860/ $\$ 7.50$

Kaplan, Max. Leisure in America. Wiley. 790.13/60-14245/ $\$ 7.50$

Lindgren, ERnest. A picture history of the cinema. Macmillan. 791.4309/60-50981/ $\$ 7.00$

LEYDA, JAY. Kino. Macmillan. 791.430947/603292/ $\$ 9.50$

Gillette, Arnold S. Stage scenery. Harper. $792.025 / 59-13576 / \$ 8.00$

Moore, Sonia. The Stanislavski method. Viking Pr. 792.028/60-1 1012/\$2.95

International theatre annual. \#4 Grove. 792.058/56-1 1494/ $\$ 4.75$

Rosenfeld, Sybil M. The theatre of the London fairs in the 18th century. Cambridge Univ. 792.0942 I $/ 60-50866 / \$ 5.50$

Blum, Daniel C. A pictorial history of the American theatre. 100 years. Chilton. 792.$097 / 60-13398 / \$ 11.50$

Dictionary of modern ballet. Tudor. 792.803/ $59-16827 / \$ 7.95$

Ballet. 9. Macmillan. 792.8084/60-6888/ $\$ 9.00$

Maynard, Olga. The American ballet. Macrae Smith. 792.80973/59-13260/\$7.50

Meerloo, Abraham M. The dance. Chilton. $793.309 / 60-4120 / \$ 4.95$

LEKIS, LisA. Dancing gods. Scarecrow. 793.319729/60-7272/ $\$ 5.00$

Taruffi, Piero. The technique of motor racing. R. Bentley. 795.72/60-1662/ $\$ 8.50$

Menke, Frank G. The encyclopedia of sports. 2nd rev. ed. Barnes. 796.03/59-8008/ $\$ 10.00$

Butler, George D. Playgrounds: their administration and operation. 3d ed. Ronald. 796.068/60-13316/\$7.00

Ledermann, Alfred. Creative playgrounds and recreation centers. F. A. Praeger. 796.$068 / 59-7455 / \$ 12.50$

Wryand, Alexander M. The cavalcade of basketball. Macmillan. 796.323/60-11609/ $\$ 5.00$

WiLKes, GLFNn. Winning basketball strategy. Prentice-Hall. 796.323/59-13902/\$4.95

Trfat, Rogre L. The encyclopedia of foot- ball. A. S. Barnes. 796.332/59-12210/ $\$ 5.95$

Claassen, Harold. Ronald encyclopedia of football. Ronald. 796.332083/60-13151/ $\$ 7.50$

Suggs, Louise. Golf for women. Doubleday. 796.352/60-9492/ $\$ 3.95$

Sports Illustrated. Book of the outdoors. Golden. 796.5/59-14665/\$12.50

DUNCAN, RaYMOND O. Introduction to physical education. Ronald. 796.4/60-15029/ $\$ 4.00$

Terrone, Leonardo F. Right and left fencing. Dodd, Mead. 796.86/59-1 1481/ $\$ 3.50$

Bracken, William R. A handbook on skiing. C. T. Branford. $796.93 / 60-2843 / \$ 2.50$

Pohndorf, Richard H. Camp waterfront programs and management. Association Pr. $797 / 60-6551 / \$ 7.50$

Ciampi, Elgin. The skin diver. Ronald. 797.23/60-7763/ $\$ 5.50$

Clarke, Arthur C. The first five fathoms; a guide to underwater adventure. Harper. $797.23 / 60-5789 / \$ 2.75$

Roberts, Fred M. Basic scuba. Van Nostrand. 797.23/60-151 36/\$8.50

Michell, Edward B. The art and practice of hawking. C. T. Branford. 799.252/60-2319/ $\$ 6.00$

\section{IJTERATURE}

Hillyer, Robret S. In pursuit of poetry. McGraw-Hill. 801.9/60-I4999/ $\$ 4.75$

Tate, Allen. Collected essays. A. Swallow. 804/59-15664/ $\$ 6.00$

EMERY, EDwin. Introduction to mass communications. Dodd, Mead. 808/60-9886/ $\$ 5.00$

MARDER, DANifL. The craft of technical writing. Macmillan. 808.066/60-5138/\$5.00

Sigband, Norman B. Effective report writing, for business, industry and government. Harper. 808.066/60-7018/ $\$ 6.75$

James, David G. Scepticism and poetry. Barnes \& Noble. 808.1/60-2377/ $\$ 5.00$

Tate, Allen (ed.) The language of poetry. Russell \& Russell. 808.1/60-6037/ $\$ 4.50$

Bryant, Donaln C. Fundamentals of public speaking. 3d ed. Appleton. 808.5/60-7702/ $\$ 5.50$

E(Royd, Donald H. Speech in the classroom. Prentice-Hall. 808.5/60-9173/ $\$ 5.25$

SandFord, William $P$. Effective business speech. 4th ed. McGraw-Hill. 808.5/60$8039 / \$ 6.75$

Krugrr, ARThur N. Modern debate, its logic

COLLEGE AND RESEARCH LIBRARIES 
and strategy. McGraw-Hill. 808.53/60-8032/ $\$ 6.50$

Elliott, Robert C. The power of satire. Princeton Univ. 808.7/60-5746/\$6.00

KNICKERBOCKER, KENNETH L. (ed.). Interpreting literature. Holt. 808.8/60-6629/ $\$ 6.50$

Ashton, Dore (ed.). Poets and the past. Andre Emmerich Gallery. 808.81/59-15251/ $\$ 5.00$

Friedman, Edward L. Toastmaster's treasury. Harper. 808.85/60-9111/\$4.95

Prochnow, Herbert V., comp. The complete toastmaster. Prentice-Hall. 808.85/60. $14291 / \$ 4.95$

Prochnow, Herbert V., comp. The speaker's book of illustrations. W. A. Wilde. 808.85/60-15265/ $\$ 2.95$

SEldEs, GeORGE, comp. The great quotations. Lyle Stuart. 808.88/58-10231/ $\$ 15.00$

Enck, John J. (ed.). The comic, in theory and practice. Appleton. 808.8893/60-8758/ $\$ 2.25$

Priestley, John B. Literature and Western man. Harper. 809.03/59-13288/ $\$ 6.95$

Glicksberg, Charles I. Literature and religion: a study in conflict. Southern Methodist Univ. 809.04/60-8675/\$4.50

Maurois, Andre. The art of writing. Dutton. 809.3/60-5994/\$4.50

Moers, Ellen. The dandy, Brummell to Beerbohm. Viking. 809.93/60-7674/\$6.00

Shumaker, WAyne. Literature and the irrational. Prentice-Hall. 809.93/60-11989/ $\$ 6.50$

Casper, Leonard. Robert Penn Warren. Univ. of Wash. 810.81/60-14114/\$4.75

Foerster, Norman (ed.). American poetry and prose. Houghton Mifflin. 810.82/60$374 / \$ 6.00$

Vanity Fair: selections from America's most memorable magazine. Viking. 810.82/60$13340 / \$ 10.00$

Bode, Carl J. (ed.). The young rebel in American literature. Praeger, 1960. 810.9/ $60-12700 / \$ 3.50$

How ARd, LEON. Literature and the American tradition. Doubleday. 810.9/60-5933/ $\$ 4.50$

Garland, Hamlin. Crumbling idols. Harvard Univ. 810.903/60-7994/\$3.50

Thorp, Willard. American writing in the twentieth century. Harvard Univ. 810.904/ $59-14739 / \$ 5.00$

Anderson, Charles R. Emily Dickinson's poetry. Holt. 811.4/60-9546/ $\$ 5.95$
Dickinson, Emily. Complete poems. Little, Brown. 811.4/60-11646/ $\$ 10.00$

Poetry Society of America. The golden year. Fine Editions Press. 811.5082/60. $1008 / \$ 6.00$

Bynner, Witter. New poems, 1960. Knopf. $811.52 / 60-12963 / \$ 3.75$

Friedman, Norman. E. E. Cummings, the art of his poetry. Johns Hopkins. 811.52/60. $9771 / \$ 4.00$

Lynen, John F. The pastoral art of Robert Frost. Yale Univ. 811.52/60-7826/\$4.50

Sergeant, Elizabeth S. Robert Frost: the trial by existence. Holt. 811.52/60-8792/ $\$ 6.00$

Howell, William D. Complete plays. Univ. $812.4 / 59-15239 / \$ 15.00$

Inge, William M. A loss of roses. Random House. 812.54/60-8376/ $\$ 2.95$

Fieldler, Leslie A. Love and death in the American novel. Criterion Books. 813.093/ $59-12195 / \$ 8.50$

MARKs, Robert. James's later novels. William-Frederick. 813.4/59-6416/ $\$ 4.50$

EMERSON, RALPH W. Early lectures; v. I. Harvard Univ. 814.3/59-5160/\$12.50

Speech Association of America. History and criticism of American public address. Russell \& Russell. 815.09/60-8199/\$15.00

Draper, Ruth. The art of Ruth Draper. Doubleday. 815.52/60-8691/ $\$ 4.95$

Granger, Bruce. Political satire in the American Revolution, 1763-1783. Ithaca, Cornell Univ. 817.109/60-4325/\$5.00

Blair, Walter. Mark Twain \& Huck Finn. Univ. of Calif. 817.4/59-15693/\$7.50

Atkinson, Alex. By rocking chair across Russia. World. 817.54/60-11457/\$3.95

Contes, Robert M. The view from here. Harcourt, Brace. 818.52/60-19037/\$3.95

Clark, Donald B. (ed.). English literature: a college anthology. Macmillan. 820.82/60$5155 / \$ 8.00$

Grebanier, Bernard D. N. Introduction to imaginative literature. Crowell. 820.82/60$6059 / \$ 7.50$

Harrison, George B. (ed.). Major British writers. Harcourt, Brace. 820.82/59-6482/ $\$ 6.50$

LifE (Chicago). Great readings from Life. Harper. 820.82/60-10411/ $\$ 7.50$

McNamee, Maurice B. (ed.). Literary types and themes. Holt. 820.82/60-5177/ $\$ 6.50$

Daiches, David. A critical history of English 
literature. 2 v. Ronald. 820.9/60-6151/ $\$ 12.50$

Dobree, Bonamy. English literature in the early eighteenth century. Oxford Univ. $820.903 / 60-95 / \$ 10.00$

Highet, Gilbert. The powers of poetry. Oxford Univ. 821.004/60-7062/\$6.00

Brooks, Ci.eanth (ed.). Understanding poetry. 3d ed. Holt. 821.082/60-10578/ $\$ 5.25$

Alspach, Russell K. Irish poetry. 2nd ed. Univ. of Penn. 821.09/59-3437/\$4.50

BRETT, R. L. Reason and imagination. Oxford Univ. 821.09/60-1030/\$2.40

Bronson, Betrand H. In search of Chaucer. Univ. of Toronto. 821.1/60-4242/\$3.50

Hartley, Lodwick C. William Cowper: the continuing revaluation. Univ. of North Carolina. 821.6/60-16254/\$5.00

Knight, Ralph (ed.). Songs and poems of Robert Burns. Twayne. 821.6/M59-1007/ $\$ 10.00$

Hirsch, ERic D. Wordsworth \& Schelling. Yale Univ. 821.7/60-6605/ $\$ 4.00$

Ridenour, George M. The style of Don Juan. Yale Univ. 821.7/60-6609/ $\$ 4.00$

Buckley, Jerome H. Tennyson: the growth of a poet. Harvard Univ. 821.8/60-13298/ $\$ 5.75$

Killham, John (ed.). Critical essays on the poetry of Tennyson. Barnes \& Noble. $821.8 / 60-3896 / \$ 5.50$

Swinburne, Algernon C. Swinburne, a selection. N. Y., Harcourt, Brace. 821.8/60$12729 / \$ 5.75$

Tompkins, Joyce M. The art of Rudyard Kipling. Humanities Press. 820.81/A60$2569 / \$ 5.00$

Durrell, Lawrence. Collected poems. Dutton. $821.912 / 60-12949 / \$ 5.00$

Hogrefe, Pearl. The Sir Thomas Moore circle. Univ. of Illinois. 822.209/59-10553/ $\$ 5.75$

Barish, Jonas A. Ben Jonson and the language of prose comedy. Harvard Univ. $822.3 / 60-7987 / \$ 5.00$

Middeton, Thomas. The changeling. Cambridge, Harvard Univ. Press. 822.3/60-94/ $\$ 3.50$

Rosen, William. Shakespeare and the craft of tragedy. Mass., Harvard Univ. Pr. $822.33 / 60-8002 / \$ 4.75$

Steinberg, M. W. (ed.) Aspects of modern drama. N.Y., Holt. 822.91082/60-8598/ $\$ 3.00$

Brewster, Dorothy. Virginia Woolf's Lon- don. New York Univ. Press. 823.912/60. $5178 / \$ 3.00$

Daiches, David. The novel and the modern world. Rev, ed. Univ. of Chicago Pr. 823.912/60-11134/\$5.00

Stallman, Robert W. (ed.). The art of Joseph Conrad. Michigan State Univ. Pr. 823.912/54-14264/\$6.50

Arnold, Matthew. Complete prose works. Univ. of Mich. 824.8/60-5018/\$6.50

Arnold, Matthew. Essays, letters and reviews. Harvard Univ. 824.8/60-7998 $\$ \$ 9.00$

Tave, Stuart M. The amiable humorist. Chicago Univ. 827.0903/59-11627/\$5.00

Graves, Robert. Food for centaurs. Doubleday. 828.912/60-8869/ $\$ 4.95$

Kennedy, Charles W. An anthology of Old English poetry. Oxford Univ. 829.1082/59. $11753 / \$ 4.50$

Rilke, Rainfr M. Selected works. v. 1 Prose; v. 2 Poetry. New Directions. 830.81/60$8714 / \$ 9.25$

MCFarLane, James $W$. Ibsen and the temper of Norwegian literature. Oxford Univ. 839.8209/60-2068/ $\$ 3.40$

Valery, Paul. Collected works. v. 3. Pantheon Books. 840.81/59-9337/ $\$ 4.50$

Camus, Albert. The possessed. Knopf. 842.914/60-7296/\$3.50

IONESCO, EugEnE. The killer, and other plays. Grove. 842.914/59-13888/\$3.95

Sartre, Jean P. The Devil and the Lord. Knopf. 842.914/59-15317/ $\$ 5.00$

Marks, Elaine. Colette. Rutgers Univ. 843.912/60-9694/ $\$ 5.00$

Beckett, Samuel B. Molloy, Malone dies and The Unnamable. Grove. 843.914/59$13886 / \$ 6.50$

Colette, Sidonie G. For a flower album. McKay. 844.912/59-12262/\$3.95

Sanctis, Francesco de. History of Italian literature. 2 v. Basic Books. 850.9/60-1600/ $\$ 12.50$

Bishop, Thомas. Pirandello and the French theater. New York Univ. 852.912/60-6419/ $\$ 4.50$

Croft-Cooke, Rupert. Through Spain with Don Quixote. Knopf. 863.3/59-15408/\$5.00

DufF, John W. A literary history of Rome from the origins to the close of the Golden Age. 3d ed. Barnes and Noble. 870.9/60. $1962 / \$ 8.75$

Duff, John W. A literary history of Rome in the Silver Age, from Tiberius to $\mathrm{Ha}$ - 
drian. 2nd ed. Barnes \& Noble. 870.9/60$1963 / \$ 10.00$

Bergson, Henri L. The philosophy of poetry: the genius of Lucretius. Philosophical Lib. 871/59-65336/ $\$ 2.75$

Poggioli, Renato. The poets of Russia, 18901930. Harvard Univ. 891.71309/60-8000/ $\$ 8.75$

Rabinowitz, Shalom. Stories and satires by Sholom Aleichem. T. Yoseloff. 892.491/59$12320 / \$ 6.00$

Gibran, Kahlil. Thoughts and meditations. Citadel. 892.78/60-15449/\$3.00

Book of THE DEAD. The book of the dead. I v. ed. Univ. Books. 893.1/60-12165/ $\$ 12.50$

Lin Yutang, comp. and tr. The importance of understanding. World. 895.1082/60$6690 / \$ 6.00$

\section{HISTORY \& BIOGRAPHY}

Shotwell, James T. The long way to freedom. Bobbs-Merrill. 900/60-7143/\$7.50

Bagby, Philip. Culture and history. Univ. of Calif. 901 $/ 60-871 / \$ 5.00$

Brinton, Clarence C. A history of civilization. 2d ed. 2 v. Prentice-Hall. 901.9/60$8503 / \$ 15.90$

Jones, Wilbur D. Civilization through the centuries. Ginn. 901.9/60-1887/\$8.75

LuCAS, HENRY S. The Renaissance and the Reformation. 2d ed. Harpers. 901.93/60. $7014 / \$ 8.50$

Alexander, Franz. The Western mind in transition. Random House. 901.94/60. $5565 / \$ 5.00$

Croce, Benedetto. History: its theory and practice. Russell \& Russell. 907.2/60. $14177 / \$ 6.00$

Year. Historic decade, 1950-1960. Year-News Front. 909.82/60-16512/\$7.95

McGraw-Hill Illustrated world geography. McGraw-Hill. 910/60-7030/\$15.00

Worldmark encyclopedia of the nations. Worldmark. 910.3/60-10438/ $\$ 30.00$

Basso, Hamilton. A quota of seaweed. Doubleday. 910.4/60-13726/ $\$ 3.95$

The Economist. The Middle East and North Africa. Oxford Univ. 912.56/60-343/\$10.00

BraIdWOOD, RoBert J. Archaeologists and what they do. F. Watts. 913.018/60-10549/ $\$ 3.95$

Concise encyclopedia of archaeology. Leonard Cottrell, ed. Hawthorn Books. 913.03/ $60-10337 / \$ 12.95$
Evans, John D. Malta. Praeger. 913.378/59$8141 / \$ 5.50$

QuenNELl, MarJorie. Everyday life in Roman and Anglo-Saxon times. Putnam. 913.42/60-1047/ $\$ 3.50$

Willemsen, Carl A. Apulia, imperial splendor in southern Italy. Praeger. 913.4757/ $59-8403 / \$ 12.50$

YAN, photographer. Turkey. Viking. 913.56I/ $60-1257 / \$ 14.00$

Columbia Univ. Columbia Collfge. Introduction to contemporary civilization in the West. 3d ed. N.Y., Columbia Univ. 914/60-16650/\$7.50

Harrison, John B. A short history of Western civilization. Knopf. 914/59-8682/ $\$ 8.50$

MeEr, Frederic van der. Atlas of Western civilization. 2d rev. ed. Van Nostrand. $914 / 60-339 / \$ 15.00$

Historical Association, London. Social life in early England. Barnes \& Noble. 914.2/ $59-15211 / \$ 4.50$

Menen, Aubrey. Rome for ourselves. McGraw-Hill. 914.5632/60-14528/\$15.00

Baedekers Autofuhrer-Verlag, Stuttgart. Spain and Portugal. Macmillan. 914.6/609435/ $\$ 6.75$

Bottineau, Yves. Spain. Rev. ed. Oxford Univ. 914.6/60-51043/ $\$ 8.50$

Stigfn, Terje. Norway. W. S. Heinman. 914.81/59-65371/\$11.50

Dumas, Alexandre. Adventures in Switzerland. Chilton. 914.94/60-1 1304/\$3.50

Payne, Robert. The splendor of Greece. Harper. 914.95/60-104I5/ $\$ 5.95$

Reischauer, Edwin O. A history of East Asian civilization. Boston, Houghton Mifflin. 915/60-4269/\$8.75

Hu, Chang-Tu. China. Taplinger. 915.1/60$7382 / \$ 10.00$

Korea: its land, people, and culture of all ages. Seoul, Hakwon-sa. 915.19/60-2998/ $\$ 25.00$

Sitwfll, Sacheverell. The Bridge of the Brocade Sash. World. 915.2/59-15323/ $\$ 8.50$

Butlfr, Grant C. Kings and camels. DevinAdair. 915.6/60-760I $\$ 4.50$

PyM, Christopher. The road to angkor. Collings. 915.96/59-4928/ $\$ 4.50$

Maclean's. Canada: portrait of a country. Hawthorn Books. 917.1/ $\$ 8.50$

American Heritage. A treasury of American Heritage. Simon and Schuster. 917.3/60. $15618 / \$ 15.00$ 
Douglas, William O. American challenged Princeton Univ. 917.3/60-12224/ $\$ 2.50$

LARrabeE, ErIc. The self-conscious society. Doubleday. 917.3/60-13540/\$3.50

LERner, Max. The unfinished country. Simon and Schuster. 917.3/59-13145/ $\$ 7.50$

Long, EDWARD J. America's national monuments and historic sites. Doubleday. 917.3/ $60-9498 / \$ 5.00$

McGinnis, Ralph J. (ed.) The good old days. Harper. 917.3/60-10861/ $\$ 10.00$

New York Times. America's taste, 1851-1959. Simon and Schuster. 917.3/60-16867/ $\$ 12.50$

Reporter. N.Y., 1949-. Our times. Farrar. 917.3/59-15071/\$6.50

Times, London. Literary Supplement. The American imagination. Atheneum. 917/3/ $60-11945 / \$ 4.50$

Toceueville, Alexis C. Journey to America. Yale Univ. 917.3/59-12699/\$6.50

Nicholls, William H. Southern tradition and regional process. Univ. of North Carolina. 917.5/60-10535/ $\$ 5.00$

Holiday. American panorama: west of the Mississippi. Doubleday. 917.8/60-8931/ $\$ 5.00$

Gudde, Erwin G. California place names. 2d ed. Univ. of Calif. 917.94/59-11311/ $\$ 10.00$

Caen, Herbert. Only in San Francisco. Doubleday. 917.9461/60-15169/\$3.95

Alaska book. J. G. Ferguson. 917.98/60-4299/ $\$ 9.95$

Foster, George M. Culture and conquest: America's Spanish heritage. Quadrangle Bks. 918/60-1351/ $\$ 6.00$

Hart, Charles W. The Tiwi of N. Australia. Holt. 919.429/60-7332/\$1.25

Schulthess, Emil. Antarctica. Simon and Schuster. 919.9/60-51784/ $\$ 15.00$

Geiger, Maynard J. The life and times of Fray Junipero Serra. Acad. of Amer. Franciscan History. 922.2/59-16949/ $\$ 12.00$

Cousins, Norman. Dr. Schweitzer of Lambarene. Harper. 922.443/60-9134/\$3.95

Wilhelmina, Queen of the Netherlands. Lonely but not alone. McGraw-Hill. 923.1492/60-14966/\$5.95

Truman, Harry S. Mr. Citizen. Random House. 923.17/60-10127/ $\$ 5.00$

Armbruster, Maxim E. The Presidents of the U. S. Horizon. 923.173/60-8159/\$4.95

Grayson, Cary T. Woodrow Wilson. Holt. 923.173/60-10998/\$3.50
Howells, William D. Life of Abraham Lincoln. Indiana Univ. 923.173/60-8917/ $\$ 6.00$

Eden, Sir Anthony. Full circle. Houghton Mifflin. 923.242/59-8856/\$6.75

Mahoney, Thomas H. D. Edmund Burke and Ireland. Harvard Univ. 923.242/60$5391 / \$ 7.50$

Moorehead, Alan. Churchill: a pictorial biography. Viking. 923.242/60-50912/\$6.50

Brandt, Willy. My road to Berlin. Doubleday. 923.243/60-10666/ $\$ 4.50$

Manvell, Roger. Dr. Goebbels, his life and death. Simon \& Schuster. 923.243/59-13878/ $\$ 4.50$

Baruch, Bernard M. Baruch: the public years. 2 v. Holt. 923.273/57-11982/ $\$ 6.00$

Thomas, Helen S. Felix Frankfurter, scholar on the bench. Johns Hopkins. 923.473/60$11571 / \$ 6.50$

Raeder, Erich. My Life. Md., U. S. Naval Dist. $923.543 / 60-9236 / \$ 6.00$

Sterling, Thomas L. Stanley's way. Atheneum. 923.942/60-7780/\$4.00

Chistiani, Leon. Pierre Teilhard de Chardin. Macmillan. 925.72/60-12446/\$3.25

Thomas, Shirley. Men of space. v. 1. Chilton Col. 926.294/60-15720/\$3.95

Warburg, Fredric. An occupation for gentlemen. Houghton Mifflin. 926.55/60-5220/ $\$ 4.50$

Sprigge, Sylvia. Berenson: a biography. Houghton Mifflin. 927/60-7386/\$5.00

Ciiagell, Marc. My life. Orion. 927.5/60$8361 / \$ 6.00$

Barbaud, Pierre. Haydn. Grove. 927.8/59$6058 / \$ 1.35$

Beecham, Sir Thomas, bart. Frederick Delius. Knopf. 927.8/60-16206/\$5.75

Boucourechliev, Andre. Schumann. Grove. 927.8/59-6060/\$1.35

Bourniquel, Camille. Chopin. Grove. 927.8/ $59-6399 / \$ 1.35$

Chevalier, Maurice. With love. Little, Brown. 927.8/60-11641/ $\$ 5.00$

Dent, Edward J. Alessandro Scarlatti: his life and works. St. Martins. 927.8/60-4215/ $\$ 6.75$

Haldane, Charlotte. Mozart. London, Oxford Univ. 927.8/60-4617/ $\$ 4.25$

Jankelevitch, Vladimir. Ravel. Grove. 927.8/59-6059/\$1.35

Klinger, George (ed.). Ludwig van Beethoven. High Fidelity Broadcasting Corp. 927.8/60-2390/\$1.00 
Schneider, Marcel. Schubert. Grove. 927.8/ $59-6097 / \$ 1.25$

Stuckenschmidt, Hans H. Arnold Schoenberg. Grove. 927.8/59-11750/\$6.00

Thayer, Alexander W. The life of Ludwig van Beethoven. 3 v. So. 11l. Univ. 927.8/59$15573 / \$ 17.50$

UNTERMEyer, Sophie. Mother is Minnie. Doubleday. 927.8/60-10672/ $\$ 3.95$

TAbori, Paul. Alexander Korda. W. S. Heinman. 927.9143/60-16294/ $\$ 5.00$

Garpenter, Margaret $H$. Sara Teasdale. Schulte. 928.1/60-9646/ $\$ 7.50$

IIolloway, Jean. Hamlin Garland. Univ. of Texas. 928.1/59-8124/\$6.00

Melville, Herman. The letters of Herman Melville. Yale Univ. 928.1 /60-7822/\$6.50

Nowell, Elizabeth. Thomas Wolfe. Doubleday. 928.1/60-8689/\$5.95

Baines, Jocelyn. Joseph Conrad. McGrawHill. 928.2/59-15429/\$8.50

Behrman, Samuel N. Portrait of Max. Random House. 928.2/60-5529/\$6.00

Krause, David. Sean O'Casey. Macmillan. 928.2/60-10782/\$4.50

Spark, Muriel. Emily Bronte, her life and work. London House and Maxwell. 928.2/ $60-2327 / \$ 4.95$

Mann, Monika. Past and present. St. Martin's. 928.3/60-8766 $\$ 44.00$

Mann, Thomas. A sketch of my life. Knopf. 928.3/60-11424/\$2.95

Gokhale, Balkrishna Govind. Ancient India, history and culture. 4th ed. Asia Pub. 934/60-3384/\$4.25

Bloch, Raymond. The origins of Rome. Praeger. 937.01/60-8075/ $\$ 6.50$

Gibbon, Edward. The decline and fall of the Roman Empire. An abridgement by D. M. Low. Harcourt, Brace. 937.06/60-12732/ $\$ 8.00$

Warmington, Brian H. Carthage. Praeger. 939.73/60-12313/\$4.50

Amsler, Jean. The illustrated history of Europe. Doubleday. 940.084/60-6125/\$14.95

Thompson, James W. Economic and social history of Europe in the later Middle Ages. F. Ungar. 940.17/60-9106/\$8.50

Flower, Desmond (ed.). The taste of courage; the war, 1939-1945. Harper. 940.53/60$13718 / \$ 10.00$

Ismay, Hastings Lionel Ismay. Memoirs. Viking. 940.53/60-14086/ $\$ 6.75$

Reynolds, Quentin J. Minister of death: the
Adolf Eichman story. Viking. 940.5405/60$1550 / \$ 5.00$

Morison, Samuel E. History of U. S. naval operations in World War II. V. 14. Little, Brown. 940.545973/47-1571/ $\$ 6.50$

Picture history of World War II, 1939-1945. Grosset \& Dunlap. 940.549/60-4744/\$7.95

Turner, Ernest S. The Court of St. James's. St. Martin's. 942/60-8768/ $\$ 5.00$

Quennell, Peter (ed.). The past we share. Prometheus. 942.0084/60-13674/\$12.50

Shirer, William L. The rise and fall of the Third Reich. Simon and Schuster. 943.086/ $60-6729 / \$ 10.00$

McInNis, EdGar. The shaping of postwar Germany. Praeger. 943.087/60-13612/ $\$ 4.00$

Macridis, Roy C. The De Gaulle republic. Dorsey. 944.082/60-14048/\$6.65

Morris, James. The world of Venice. Pantheon Books. 945.31/60-11763/ $\$ 5.00$

Carmichael, Joel. An illustrated history of Russia. Reynal. 947.0084/60-4842/\$20.00

Olschki, Leonardo. Marco Polo's Asia. Univ. of Calif. 950.1/60-8315/\$10.00

Debary, William T. (ed.). Sources of Chinese tradition. Col. Univ. 951.0082/60$9911 / \$ 7.50$

Barnett, A. Doak. Communist China and Asia. Harper. 951.05/60-5956/ $\$ 6.95$

Carrasco, Pedro. Land and polity in Tibet. Univ. of Wash. 951.5/59-14773/ $\$ 5.75$

Lfngyel, EmIL. The changing Middle East. John Day. 956/60-7661/ $\$ 5.75$

Human Relations Area Files, Inc. Laos; its people, its society, its culture. Taplinger. 959.4/60-7381/\$6.50

Parkinson, Cyril N. British intervention in Malaya. 1867-1877. Oxford Univ. 959.5/60$50031 / \$ 7.20$

HaHn, LoRna. North Africa: nationalism to nationhood. Public Affairs. 961.03/60$11401 / \$ 6.00$

Kimble, George H. T. Tropical Africa. 2 vols. Twentieth Century Fund. 967/60$15160 / \$ 15.00$

Stoutenburgh, John L. Dictionary of the American Indian. Philosophical Lib. 970. $103 / 60-9635 / \$ 10.00$

DeLaguna, Frederica. The story of a Tlingit community. U. S. Govt. Printing Office., Supt. of Doc. 970.3/60-60629/\$2.00

James, Harry C. The Cahuilla Indians. Westernlore. 970.3/60-10491/ $\$ 7.50$

Wilson, Edmund. Apologies to the Iroquois. Farrar. 970.3/59-9177/ $\$ 1.95$ 
Colton, Harold S. Hopi kachina dolls. Univ. of New Mexico. 970.62/59-5480/\$8.00

Kroeber, Alfred L. Fishing among the Indians of northwestern California. Univ. of Calif. 970.66392/60-6519/ $\$ 4.50$

BrebNer, JoHn B. Canada. Univ. of Michigan. 971/59-62500/\$10.00

Adams, James T. Album of American history. v. 5, 1917-1953. Scribner. 973.084/44$706 / \$ 12.50$

Bakeless, John E. Turncoats, traitors, and heroes. Lippincott. 973.385/59-5406/\$6.50

Bemis, Samuel F. Pinckney's treaty. Yale Univ. 973.43/60-13681 $/ \$ 6.00$

American Heritage. The American Heritage picture history of the Civil War. Amer. Heritage. 973.79/60-10751/\$19.95

Thompson, William F., JR. The Image of war; the pictorial reporting of the American Civil War. Yoseloff. 973.79/60-11901/ $\$ 7.50$

KNIGHT, Oliver. Following the Indian wars. Univ. of Oklahoma. 973.7/60-8751 $/ \$ 5.95$

McKitrick, Eric L. Andrew Johnson and reconstruction. Univ. of Chicago. 973.81/60$5467 / \$ 8.50$
Koenig, Louis W. The invisible presidency. Rinehart. 973.91/60-5341/\$6.95

Schlesinger, Arthur M. The age of Roosevelt. v. 3. Houghton Mifflin. 973.917/56$10293 / \$ 6.95$

Forbes, JACK D. Apache, Navaho and Spaniard. Univ. of Okla. 979/60-13480/ $\$ 5.95$

Waters, Frank J. The Earp brothers of Tombstone. C. N. Potter. 979.153/60-8927/ $\$ 5.00$

Stewart, George R. Donner Pass and those who crossed it. Lane. 979.437/60-8367/ $\$ 1.95$

Singletary, Otis A. The Mexican War. Univ. of Chicago. 973.62/60-7248/\$3.75

Chisholm, James. South Pass, 1868. Univ. of Nebraska. 978.763/60-12692/ $\$ 4.50$

BeEbe, Lucius. San Francisco's golden era. Howell-North. 979.461/60-15642/\$5.95

Steward, Julian H. (ed.). v. 7. Handbook of South American Indians. Govt. Printing Office. Supt. of Docs. 980.1/46-26504/\$2.00

VleKKe, BERNARd N. Nusantara: a history of Indonesia. Quadrangle Books. 991/59. $4657 / \$ 10.00$

\section{American Library Annual}

In the new American Library and Book Trade Annual for 1961, it is noted that the total number of degrees granted in 1959 was 464,008; of these, 1,967 were in librarianship, making 1959 a peak year for qualifying librarians. In proportion to all degrees conferred the percentage of those in librarianship remained constant, for over the previous year there was an increase of 5.4 per cent in the graduating aggregate and this same increase was borne out by the library schools. Of the 1,967 library graduates the placement of 1,359 was analyzed as to salary highs and lows. Considered in relation to personnel in other fields, - the salaries of beginning librarrians compares favorably. The average starting salary was given as $\$ 4,862$. The record high was an exceptional $\$ 10,000$, although a more usual high ran in the regions of a respectable $\$ 7,000$. Possibly reflecting the current educational expansion, more graduates-a total of 418-went into college and university libraries, 280 into school libraries, 342 into municipal libraries, 230 into libraries of a specialized nature, and 77 into regional and county libraries. 